\title{
SUPREME COURT REVIEW
}

\section{FOREWORD: TRANSPARENT ADJUDICATION AND SOCIAL SCIENCE RESEARCH IN CONSTITUTIONAL CRIMINAL PROCEDURE}

\section{TRACEY L. MEARES* \& BERNARD E. HARCOURT**}

The October 1999 Term was a year of consolidation in the law of police investigations in constitutional criminal procedure. In four short and compact opinions-three supported by sizeable majorities and three written by the Chief Justice-the Supreme Court synthesized and consolidated its criminal procedure jurisprudence, and offered clear guidance to law enforcement officers and private citizens alike. Miranda warnings are required by the Fifth Amendment, and the police must continue to "Mirandize" citizens before conducting any custodial interrogations. ' Reasonable suspicion under the Fourth Amendment calls for a totality-of-the-circumstances test, and a

Professor of Law, The University of Chicago; Director of the Center for Studies in Criminal Justice, The University of Chicago; and Research Fellow, American Bar Foundation

** Associate Professor of Law, The University of Arizona, and Director of the University of Arizona Rogers Program on Law, Philosophy and Social Inquiry.

We are grateful for extensive comments on an earlier draft to Michael Dorf, Jeff Fagan, Sam Gross, Yale Kamisar, Wayne LaFave, Richard Leo, Toni Massaro, Marc Miller, Ted Schneyer, Steve Schulhofer, Chris Slobogin, Carol Steiker, Bill Stuntz, Mark Tushnet, Adrian Vermeule and the participants in the University of Arizona Summer Work-in-Progress Workshop. We gratefully acknowledge the support of our research assistants, Leif Olson and Justin Sandberg at the University of Chicago and Theresa Hernandez and Craig LaChance at the University of Arizona. The Arnold and Frieda Shure Research Fund and the Hans Ziesel Research Fund at The University of Chicago provided financial support.

${ }^{1}$ See Dickerson v. United States, 120 S.Ct. 2326 (2000). 
citizen's flight from the police in a high crime neighborhood amounts to reasonable suspicion sufficient to justify a Terry stop and frisk. ${ }^{2}$ In contrast, a tip from an anonymous informant merely describing a suspect does not give rise to reasonable suspicion. ${ }^{3}$ The reasonable expectation of privacy test continues to govern whether the Fourth Amendment protections are triggered, and travelers have a reasonable expectation of privacy in opaque soft-sided luggage. ${ }^{4}$

We have differences of opinion as to the outcome in some of these cases. And we have sharply disagreed in the past about the soundness of other criminal procedure decisions. Last Term, for instance, we parted company on the desirability and constitutionality of Chicago's anti-gang loitering ordinance. In the Morales litigation, one of us, Tracey Meares, co-authored an amicus brief in support of the ordinance and directed the Supreme Court's attention to empirical evidence of its effectiveness in combating gang-related violence in Chicago. ${ }^{5}$ Bernard Harcourt took issue with Meares on both the wisdom and the validity of the Chicago ordinance and challenged the empirical foundation for one of the principal theories behind the ordinance, namely the broken windows theory. ${ }^{6}$ Still today, we disagree strongly about what the empirical evidence proves, how to approach the empirical issues, and how properly to balance the interests at stake.

${ }^{2}$ See Illinois v. Wardlow, 120 S. Ct. 673 (2000).

${ }^{3}$ See J.L. v. Florida, 120 S. Ct. 1375 (2000).

'See Bond v. United States, 120 S. Ct. 1462 (2000).

${ }^{5}$ See Brief Amicus Curiae of the Chicago Neighborhood Organizations in Support of Petitioner, Chicago v. Morales, 119 S.Ct. 1849 (1999) (No. 97-1121), available in LEXIS, Supreme Court Cases and Materials Library, U.S. Supreme Court Briefs File; see also Dan M. Kahan \& Tracey L. Meares, Foreword: The Coming Crisis of Criminal Procedure, 86 GEORGETOWN LAW JOURNAL 1153 (1998).

${ }^{6}$ See Bernard E. Harcourt, Reflecting on the Subject: A Critique of the Social Influence Conception of Deterrence, the Broken Windows Theory, and Order-Maintenance Policing New York Style, 97 Michigan Law Review 291 (1998); see also Bernard E. Harcourt, Matrioshka Dolls, in URGENT TIMES: POLICING AND RIGHT IN INNER CITY COMMunities (1999).

$\rightarrow$ Compare Tracey L. Meares \& Dan M. Kahan, Law and (Norms of) Order in the Inner City, 32 LAW \& SOC'y REviEw 805 (1998) $u \dddot{\rightarrow}$ Bernard E. Harcourt, After the "Social Meaning Turn": Implications for Research Design and Methods of Proof in Contemporary Criminal Law Policy Analysis, 34 LAW \& SOC'Y REVIEW 179 (2000). 
In this Foreword, however, we put aside our differences and link arms to call for a new generation of criminal procedure jurisprudence, one that places empirical and social scientific evidence at the very heart of constitutional adjudication. We are calling for a mode of judicial decision-making and academic debate that treats social scientific and empirical assessment as a crucial element in constitutional decision-making, thereby making criminal procedure decisions more transparent. By more transparent, we mean to describe adjudication that expressly and openly discusses the normative judgments at the core of constitutional criminal procedure. Judicial decisions that address the relevant social science and empirical data are more transparent in that they expressly articulate the grounds for factual assertions and, as a result, more clearly reflect the interpretive choices involved in criminal procedure decision-making. We are not so naive or idealistic as to think that increased attention to empirical evidence will guarantee right answers in criminal procedure cases. But use of empirical evidence will produce a clearer picture of the existing constitutional landscape and spotlight the normative judgments at the heart of criminal procedure cases.

In this sense, we are calling for a third path in the larger constitutional debate between Richard Posner's empiricism and Ronald Dworkin's interpretivism. We agree with Posner that "the lack of an empirical footing . . . always has been the Achilles heel of constitutional law, not the lack of a good constitutional theory," but we are not writing against constitutional theory. To the contrary, we endorse the Court's balancing-ofinterests jurisprudence in the criminal procedure context and suggest that it in fact invites consideration of empirical evidence in the normative task of weighing competing constitutional interests. We emphasize, however, that the need for increased attention to social science data is equally important under more formalist or rights-oriented jurisprudential approaches. We agree with Dworkin that interpretive judgments are central to constitutional decision-making, but we disagree with his claim

\footnotetext{
${ }^{8}$ Richard Posner, Against Constitutional Theory, 73 N.Y.U. L. REv. 1 (1998).
} 
that these judgments can be made in an empirical vacuum. ${ }^{9}$ Theoretical principles cannot properly resolve difficult criminal procedure cases without the assistance of empirical evidence. The most current and reliable empirical and social scientific evidence must inform the normative judgments at the heart of constitutional criminal procedure.

Indeed, greater attention to empirical and social science evidence is necessary precisely in order to shed better light on the normative judgments that we make in criminal procedure. We are writing this Foreword together to emphasize that the turn toward empirical and social scientific research is neither ideologically motivated, nor outcome determinative. In the words of another commentator, "Facts cannot replace constitutional theory, nor can they mechanistically resolve questions posed by theory. Instead, empirical knowledge is most useful in unmasking the theoretical assumptions that undergird constitutional law, in focusing those theories, and in contributing to a multidimensional view of society that informs the substance of constitutional law."

\section{The LANDSCAPE OF MODERN CRIMINAL PROCEDURE}

Modern constitutional criminal procedure emerged in a legal culture shaped by American legal realism and historically has been driven by empirical and pragmatic concerns about police practices, police-civilian encounters, crime prevention and detection, and civil liberties. One of the most notable features of the constitutionalization of criminal procedure in the 1960s was the Supreme Court's focus on the realities of street policing, custodial interrogations, investigations, and the impact of these activities on individual freedoms. Judicial decisions and academic writing in modern criminal procedure, to a far greater extent than in most legal fields-especially other areas of constitutional law-routinely centered on empirical issues surrounding the effectiveness of police practices and their impact on

${ }^{9}$ See Ronald Dworkin, Social Sciences and Constitutional Rights-the Consequences of Uncertainty, 6 J.L. \& EDUC. 3 (1977).

${ }^{10}$ Deborah Jones Merrit, Constitutional Fact and Theory: A Response to Chief Judge Posner, 97 MrCH. L. REV. 1287 (1999). 
liberty interests.

The Court's recognition and embrace of real world experience forced a rejection of the formalism characteristic of nineteenth century Fourth and Fifth Amendment decisions. ${ }^{11}$ Modern criminal procedure jurisprudence gravitated naturally toward a balancing-of-interests approach. As a result, it is commonplace today to describe constitutional rights relating to criminal procedure as guaranteeing a reasonable balance between liberty and order. ${ }^{12}$ While recognition of this kind of balancing is thought to be the hallmark of interpreting the guarantees of the Fourth Amendment, ${ }^{13}$ it is also relevant to analysis of the Fifth and Sixth Amendments as well. ${ }^{14}$ It reflects, in effect, a larger form of constitutional reasoning that has become, as Alexander Aleinikoff remarked in a 1987 article, "widespread, if not dominant, over the last four decades."

We refer to this balancing of liberty and order interests as a "balancing-of-interests" jurisprudential approach. It is different than the conventional balancing test used in cases like Mathews $v$. Eldridge, which weighs costs and benefits in a particular case. It calls, instead, for balancing liberty and order interests at a higher level-at the level of formulating criminal procedure rules, like the requirement of "reasonable suspicion" rather than "probable cause" in the stop-and-frisk encounter, or the extension of the concept of "legal compulsion" to the police station house under the Fifth Amendment.

The Court's tendency to engage in this kind of balancing in the constitutional criminal procedure context is pervasive. So

"For examples of that formalism, see Boyd v. United States, 116 U.S. 616 (1886) (elucidating the relationship between the Fourth and Fifth Amendments); Weeks v. United States, 232 U.S. 383 (1914) (discussing Fourth Amendment); Olmstead v. United States, 277 U.S. 438 (1928) (discussing Fourth Amendment).

${ }^{12}$ See, e.g., Kansas v. Hendrick, 521 U.S. 346 (1997).

${ }^{13}$ See, e.g., United States v. Leon, 468 U.S. 897 (1984).

${ }^{14}$ With regard to the Fifth Amendment, see infra notes 77-153 and accompanying text; with regard to the Sixth Amendment, see, e.g., Argersinger v. Hamlin 407 U.S. 25 (1972).

$\rightarrow$ T. Alexander Aleinikoff, Constitutional Law in the Age of Balancing, 96 YALE L.J. 943, 943 (1987); see also Symposium, When Is a Line as Long as a Rock Is Heavy?: Reconciling Public Values and Individual Rights in Constitutional Adjudication, 45 HASTINGS L.J. 707 (1994). 
pervasive, in fact, that it is often taken for granted. Consider the case of Schneckloth $v$. Bustamonte. ${ }^{16}$ This case is best known for establishing a fact-intensive totality-of-the-circumstances review where a suspect has consented to a police search. In Schneckloth, the Court refused to require that the consenting individual have knowledge of her right to refuse the search as a prerequisite to establishing voluntariness. ${ }^{17}$ Instead, the Court adopted a totality-of-the-circumstances test to assess whether the person searched consented to the police action. ${ }^{18}$ While the totality-of-the-circumstances test is not itself a balancing analysis, ${ }^{19}$ notice how the Court defined the voluntariness test in Schneckloth:

As with police questioning, two competing concerns must be accommodated in determining the meaning of a "voluntary" consent-the legitimate need for such searches and the equally important requirement of assuring the absence of coercion. ${ }^{20}$

In other words, the Court treated "voluntariness" itself as a balancing of the needs of efficient law enforcement and protection against coercion-of order and liberty. The assessment of "voluntariness" is by no means simply an assessment of the consenting party's state of mind at the time of the search and consent. ${ }^{21}$ Nor is "voluntariness" merely a question of the propriety of police conduct, such as the failure to apprise an individual of her right to refuse the search. ${ }^{22}$ Instead, the Court made "voluntariness" a placeholder for an analysis of the competing interests of order and liberty-for a balancing-of-interests approach. In effect, it is the resulting balancing that determines the scope of the right. ${ }^{23}$

\footnotetext{
${ }^{16} 412$ U.S. 218 (1973).

${ }^{17}$ See id., 412 U.S. at 224.

${ }^{18}$ See id. at 226.

${ }^{19} \mathrm{See}, \epsilon \rightarrow$ Aleinikoff, supra note 15 at 945 (distinguishing balancing from "totality of the circumstances" approaches).

${ }^{20} 412$ U.S. at 227.

${ }^{21}$ See id. at 224.

${ }^{22}$ See id. at 226.

${ }^{23}$ See id. at 224-25 ("Voluntariness has reflected an accommodation of the complex of values implicated in police questioning of a suspect."). Attention to the balancing that underlies Schneckloth's totality-of-the-circumstances test could bring greater clarity
} 
The gradual and relatively recent emergence of modern criminal procedure-and with it, of the balancing-of-interests approach in constitutional criminal procedure-has been a mixed blessing. On the one hand, the adoption of balancing tests may promote a potentially more transparent mode of judicial decision-making in criminal procedure. Explicit balancing may encourage the judiciary to be more honest about the inevitable value judgments that courts do and must make. ${ }^{24}$ It is an approach that may render the judiciary more accountable to the American public and more open to criticism.

On the other hand, the lack of a full-blown realist critique of the criminal procedure field may have undermined the quality of the balancing tests used in constitutional criminal procedure. In many judicial opinions and, often, in academic commentary, balancing is merely a veil that masks bald assertions of political ideology. Rather than guiding the decisionmaking process, criminology, police studies, and the social sciences are often deployed as mere rhetorical flourishes, as tropes, or as mythology.

The result is that, today, constitutional criminal procedure decisions are often marred by spotty or inconsistent application of balancing tests and by pseudo-empirical statements about the importance of law enforcement and the sanctity of individual liberty. We are all familiar with these rhetorical flourishes in judicial opinions. Without seriously taking account of empirical research, the Supreme Court strikes down rules of criminal procedure because they "fail to protect privacy . . . and impede ef-

and more refinement to the concept of "voluntariness" embedded in the ideal of consent. For instance, if a police officer has probable cause for a search, but no warrant, then perhaps we would balance the concept of voluntariness for consent in a different way than if the police officer does not have probable cause, nor a search warrant, but manages to elicit consent for the search anyway. The balance that we might strike between liberty and order in the voluntariness assessment may be different in different situations. Perhaps we might require a warning where the police have no probable cause, but not where they do. The law of consent might be improved if these kinds of considerations were included.

${ }^{24}$ See also, Silas J. Wasserstrom \& Louis Michael Seidman, The 4th Amendment as Constitutional Theory, 72 GEO. L.J. 19, 46 (1988) (noting that "by candidly addressing competing interests the Court encourages dialogue about the weight to be attached to those interests") (citing Wallace Mendelson, On the Meaning of the 1st Amendment: Absolutes in the Balance, 50 CALIF. L. REV. 821, 825 (1962) (making similar point)).

${ }^{25}$ See Dean M. Hashimoto, Science as Mythology in Constitution Law, 76 OrEgON L. REV. 111 (1997). 
fective law enforcement." ${ }^{26}$ The Court upholds other rules, again without fully assessing the empirical evidence, because they embody a "carefully crafted balance designed to fully protect both the defendant's and society's interests." ${ }^{27}$ We all recognize that these are, after all, purely rhetorical statements intended to render authoritative the Court's decisions. Cases where the Supreme Court relies solidly on social scientific evidence-such as United States $v$. Leon ${ }^{28}$-are few and far between, and, curiously, are condemned by some legal academics simply because they looked to such evidence. ${ }^{29}$

Recently, dissatisfaction with the balancing approach has led one group of commentators to advocate a return to more formalist modes of decision-making in criminal procedure, and in legal and constitutional theory generally. Justice Antonin Scalia has argued for, and implemented in his opinions, a form of textualism in criminal procedure that focuses on the practices that prevailed at the time of the Founding. ${ }^{30}$ In determining whether a search and seizure violates the Fourth Amendment, for example, Scalia has declared that the first inquiry must be "whether the action was regarded as an unlawful search and seizure under the common law when the Amendment was framed." ${ }^{31}$ It is only where the inquiry yields no answer that Scalia will engage the balancing test. Similarly, Professor Morgan Cloud has advocated greater formalism out of a concern that the Court's pragmatic balancing approach sys-

${ }^{26}$ California v. Acevedo, 500 U.S. 565 (1991); see also United States v. Watson, 423 U.S. 411 (1976) ("[A] constitutional rule permitting felony arrests only with a warrant or in exigent circumstances could severely hamper effective law enforcement."); Illinois v. Gates, 462 U.S. 213 (1983) (rejecting "two-prong test" [of Aguilar-Spinelli] because it "cannot avoid seriously impeding the task of law enforcement").

${ }^{27}$ Moran v. Burbine, 475 U.S. 412, 433 n.4 (1986).

${ }^{28} 468$ U.S. 897 (1984).

${ }^{29}$ See, e.g., Laurence Tribe, Seven Deadly Sins of Straining the Constitution Through a Pseudo-Scientific Sieve, 36 HASTINGs L. J. 155 (1984); Yale Kamisar, Does (Did) (Should) the Exclusionary Rule Rest on a "Principled Basis" Rather than an "Empirical Proposition"?, 16 CREIGHTON L. REv. 565 (1983); Albert Alschuler, Close Enough For Government Work: The Exclusionary Rule After Leon, 1984 Sup. Ct. Rev. 309.

${ }^{30}$ See generally Antonin Scalia, Common-Law Courts in a Civil-Law System: The Role of United States Federal Courts in Interpreting the Constitution and Laws, in A MATTER OF INTERPRETATION: FEDERAL COURTS AND THE LAW (Amy Gutmann ed., 1997); see, e.g., Wyoming v. Houghton, 526 U.S. 295 (1999).

${ }^{31}$ Wyoming v. Houghton, 526 U.S. 295, 299 (1999). 
tematically tilts against protection of individual interests. ${ }^{32}$ Cloud states, "[T] he Fourth Amendment embodies a normative choice favoring individual autonomy over government authority ... only a rule-based interpretative theory can preserve that choice." ${ }^{33}$

A second group of criminal procedure commentatorsthose who subscribe to rights-oriented liberalism-also take issue with the idea of balancing liberty interests against the interests of law enforcement in formulating the scope of constitutional rights. Although interpretive in nature, the idea of "rights as trumps" does not necessarily allow for such balancing of interests. The trump metaphor, naturally, comes from Ronald Dworkin's description of rights-oriented liberalism. Commentators in this camp resist weighing the interests of law enforcement in defining the scope of rights. In the Fifth Amendment context, for instance, Justice Thurgood Marshall maintained that "whether society would be better off if the police warned suspects of their rights before beginning an interrogation or whether the advantages of giving such warnings would outweigh their costs did not inform the Miranda decision." ${ }^{34}$ A large number of criminal procedure scholars also hold this position, including, for instance, Stephen Schulhofer and Charles Weisselberg. ${ }^{35}$ Weisselberg writes that "Miranda expressly represents a preference for Fifth Amendment values over the interests of law enforcement officers in obtaining incriminating statements," thereby implying that the contours of the Fifth Amendment are determined absent a balancing of law enforcement interests. ${ }^{36}$ This is often referred to as the "original vision" of Miranda by its proponents-a vision of the

${ }^{32}$ See Morgan Cloud, Pragmatism, Positivism, and Principles in Fourth Amendment Theory, 41 UCLA L. REV. 199 (1993).

${ }^{33} I d$. at 204.

${ }^{34}$ New York v. Quarles, 467 U.S. 649, 682 (1984) (Marshall, J., dissenting).

${ }^{35} \rightarrow$ Stephen J. Schulhofer, Reconsidering Miranda, 54 U. CHI. L. REV. 435, 436-37 (1987) (analyzing the two core holdings of Miranda without reference to law enforcement interests); Charles D. Weisselberg, Saving Miranda, 84 CORNELL L. REv. 109, 121 (1988).

${ }^{36}$ Weisselberg, supra note 35 , at 121; see also id. at 140-41 (suggesting Fifth Amendment values are complex, but do not include effective law enforcement). 
decision and the Fifth Amendment that focuses on individual autonomy but disregards the interests of law enforcement.

A third group of commentators-including Michael Dorf, ${ }^{37}$ David Faigman, ${ }^{38}$ and Richard Posner ${ }^{39}$-have called instead for continued pragmatism accompanied by increased use of social scientific and empirical studies in constitutional decisionmaking, and, by implication, in constitutional criminal procedure as well. At the more tepid end of the spectrum, in his Foreword to the 1997 Term Michael Dorf argues that the Court has paid insufficient attention to social science research and to the actual impact of the Court's decisions. Though not overly sanguine, Dorf does suggest that it would be a "step in the right direction" and might result in "marginal improvements" for the Supreme Court to take account of the social consequences of its decisions. $^{40}$ Dorf argues in his other work for a constitutional approach of pragmatism-as-contextualism that wraps greater empiricism within a more pragmatic constitutional decisionmaking process. ${ }^{41}$

At the other end of the spectrum, David Faigman argues that the Court traditionally has engaged in "constitutional factfinding" as a way to reach normative judgments in interpreting the Constitution, and has increasingly been called upon to explain divergences between its judgments and empirical research. ${ }^{42}$ Faigman criticizes "the Court's empirical myopia" and suggests that it may undermine the Court's political legitimacy. ${ }^{43}$ $\mathrm{He}$ is somewhat more optimistic than Dorf about the potential impact of increased attention to empirical research, and suggests that constitutional fact-finding may in fact constrain the

${ }^{37}$ See Michael Dorf, Foreword: The Limits of Socratic Deliberation, 112 HARV. L. REV. 4 (1998).

${ }^{38} \rightarrow$ David L. Faigman, "Normative Constitutional Fact-Finding": Exploring the Empirical Component of Constitutional Interpretation, 139 U. PA. L. REv. 541 (1991).

${ }^{39}$ See Posner, supra note 8.

${ }^{40}$ Dorf, supra note 37, at 8, 51; see generally id. at 51-60.

${ }^{41}$ See Michael Dorf, Create Your Own Constitutional Theory, 87 CAL. L. REV. 593 (1999).

${ }^{42} \rightarrow$ Faigman, supra note 38 , at 550 .

$\rightarrow$ Id. at 612 . 
Court. $^{44}$

In a similar vein, Richard Posner argues that the Supreme Court should make greater use of the social sciences in constitutional adjudication. ${ }^{45}$ Posner argues, against constitutional theory and constitutional law theorists, that the weakness in the Court's decisions lies not in a lack of theorizing, but in inattention to facts. On this ground, Posner recommends that "the legal professoriat redirect its research and teaching efforts toward fuller participation in the enterprise of social science, and by doing this make social science a better aid to judges' understanding of the social problems that get thrust at them in the form of constitutional issues."

A final group of commentators also take an empirical approach, but they come to yet a different conclusion. Commentators such as Gerald Rosenberg ${ }^{47}$ and William Stunt ${ }^{48}$ take the position that criminal procedure rights-whether arrived at through balancing, new formalism, or rights-oriented liberalism-are ineffective in bringing about real change in the criminal justice system. They stress the importance of other factorspopular support or legislative action for Rosenberg, substantive criminal law and funding issues for Stuntz-in order to get a better handle on the police-citizen relationship.

Our position makes room for both empiricism and interpretivism. With the pragmatists and empiricists, we call for greater attention to empirical and social science research. In this respect, our position is simple: constitutional criminal procedure decision-making informed by the social sciences and empirical research is better than lawmaking uninformed by such research; and, in the criminal procedure realm, relevant empirical data are available and knowable - perhaps not perfectly - but reasonably reliably. With the interpretivists, however, we contend that criminal procedure decision-making is a

\footnotetext{
${ }^{44} \rightarrow: i d$. at 601.

${ }^{45}$ See Posner, supra note 8, at 11-12.

${ }^{46} I d$. at 12.

47 See Gerald Rosenberg, The Hollow Hope: Can Courts Bring About Social CHANGE, 304-35 (1991).

${ }^{48} \rightarrow$ William J. Stuntz, The Uneasy Relationship Between Criminal Procedure and Criminal Justice, 107 YALE L.J. 1 (1997).
} 
function of interpretive judgment. The relevant empirical facts, we claim, are not outcome determinative. They do not compel particular resolutions, nor do they guarantee right answers. The resolution of criminal procedure cases calls for normative judgments-in particular, for a balancing of liberty and orderand is not dictated by empirical evidence. When taken together, an emphasis on the use of relevant empirical facts in the context of a pragmatic balancing approach to criminal procedure decision-making, we believe, holds out the greatest promise of increasing the transparency of these constitutional decisions and, therefore, potentially increasing the accountability of the Court to the public.

At the level of constitutional theory, then, we endorse the interpretive balancing-of-interests test that the Court so often uses in criminal procedure. Although we do not necessarily agree with the outcome that balancing may produce in the Supreme Court's hands, we endorse balancing as a jurisprudential approach for two reasons. First, the reality is that, at least in criminal law and procedure, we always do balance the costs to law enforcement and personal security. So, for instance, we do not prohibit all custodial interrogation in order to protect the Fifth Amendment. Nor do we require proof beyond all possible doubt. We always take into consideration the effects on the police function. Whether we like it or not, courts simply do adjust the scope of rights based on those costs. Better that we should be explicit about the balancing and articulate the interpretive choice than deny the role of order interests and nevertheless engage in balancing sub silentio.

Second, we endorse the balancing test because of the conception of rights that it promotes. Defining the scope of a criminal procedural right as a process of detecting the appropriate balance between societal interests in safety, on the one hand, and freedom from unnecessary government intrusions, on the other, envisions rights as flexible and contextual, as accommodating of changes in political and social climate, and as political and instrumental. ${ }^{49}$ Justice White eloquently expressed

${ }^{49}$ See Tracey L. Meares \& Dan M. Kahan, When Rights Are Wrong: The Paradox of Unwanted Rights in URGENT TIMES: POLICING AND Rights IN INNER CITY COMMUNITIES, su- 
this conception of rights in his dissenting opinion in Miranda:

That the Court's holding today is neither compelled nor even strongly suggested by the language of the Fifth Amendment . . . does not prove either that the Court has exceeded its powers or that the Court is wrong or unwise in its present reinterpretation of the Fifth Amendment. It does, however, underscore the obvious-that the Court has not discovered or found the law in making today's decision, nor has it derived it from some irrefutable sources; what it has done is to make new law and new public policy in much the same way that it has in the course of interpreting other great clauses of the Constitution. This is what the Court historically has done. Indeed, it is what it must do and will continue to do until and unless there is some fundamental change in the constitutional distribution of governmental powers.

This, we argue, is the right way to think about criminal procedure rights. In this field, at least, rights are a legal device that we, as a society and through our courts, craft in order to promote a particular vision of society and of the police-citizen encounter. To be sure, we are not suggesting that the Court can simply disregard the written text of the Constitution. The text and history of the Constitution will, of course, exclude a vast number of possible conceptions of rights. As Richard Posner suggests, no constitutional theory "is required to determine how many Senators each state may have." ${ }^{\text {"11 }}$ Like Posner, we agree that "there are large areas of constitutional law that the debates over constitutional theory do not touch and that consequently [we] shall ignore." ${ }^{52}$ But in the difficult cases of criminal procedure interpretation-cases, for instance, about what amounts to reasonable suspicion or whether the privilege against compelled self-incrimination extends to the police station house-the scope of constitutional rights is more properly viewed as a vehicle to promote a vision of society rather than an inherited or cloistered stakehold. This way of thinking about rights embraces balancing as the procedural tool, as the decision-making mechanism. Balancing recognizes societal interests in both lib-

pra note 6, at 6-11 (describing criminal procedure rights); see also Bernard E. Harcourt, Matrioshka Dolls in URGent TIMES: POLICING AND Rights IN INNER CITY COMMUNITIES, supra note 6 , at 81-82.

${ }^{50}$ Miranda, 384 U.S. at 531.

${ }^{51}$ Posner, supra note 8, at 2.

${ }^{52} I d$. 
erty and order, and articulates the resulting accommodation in individual cases.

The primary purpose of this Foreword, though, is not to defend this conception of rights. It is, instead, to call for greater attention to social scientific and empirical research in constitutional criminal procedure. The important point is that, even if one were to adopt a more formalist or rights-oriented or other jurisprudential approach to criminal procedure, the need for greater empiricism remains just as strong. Reliance on evidence about the real world in very real world criminal justice cases will make these decisions better.

What we are calling for, then, is greater attention to social science data regardless of the constitutional theory that one espouses-not against constitutional theory. A helpful illustration of decision-making informed by empirical research is the Court's decision in United States $v$. Leon. ${ }^{53}$ Leon presented the question whether evidence obtained in a search of the defendant's home by police officers, who relied on a search warrant that ultimately was found to be invalid, should be excluded. The Court chose to resolve the question by "weighing the costs and benefits of preventing the use in the prosecution's case-inchief of inherently trustworthy tangible evidence." ${ }^{54}$ The benefit of admitting such information is primarily that it brings to the court's attention inherently trustworthy evidence that supports the conviction of a criminal offender. Such convictions promote the maintenance of order.

The costs, of course, are bound up in the reasons for having and enforcing the exclusionary rule in the first place. That rule is designed to deter misconduct by police officers and to preserve the integrity of the judicial forum. Consistent with the Court's jurisprudence since the seventies, ${ }^{55}$ the Leon Court emphasized the goal of deterring police misconduct, and ultimately ruled that the exclusion of evidence in these cases would

${ }^{53} 468$ U.S. 897 (1984).

${ }^{54} \mathrm{Id}$. at 907.

${ }^{55}$ See, e.g., United States v. Ceccolini, 435 U.S. 268, 280 (1978); United States v. Calandra, 414 U.S. 338, 348-52 (1974); cf. Calandra, 414 U.S. at 355-60 (Brennan, J., dissenting). 
not advance that goal.

In reaching its conclusion, the Court relied heavily on social science studies. For example, Justice White, writing for the majority, pointed to nascent research on the effect of the exclusionary rule on the disposition of felony arrests. Justice White noted that the operation of the exclusionary rule appeared to result in the nonprosecution or nonconviction of only a small percentage of individuals, but he stated, "the small percentages with which [the researchers] deal mask a large absolute number of felons who are released because the cases against them were based in part on illegal searches or seizures." ${ }^{, 56}$ Justice White then concluded that the potential for large numbers of felons to go free militated against application of the exclusionary rule where there was no basis-and where the Court had been offered none-"to believe that exclusion of evidence . . . will have a significant deterring effect on the issuing judge or magistrate." ${ }^{, 7}$

Justices Brennan and Marshall in dissent emphasized concern for the integrity of the judicial forum as the primary reason to reject a good faith exception to the exclusionary rule. The dissenters also pointed to empirical evidence-the same studies relied upon by the majority ${ }^{58}$ - to argue that the costs of the exclusionary rule were "quite low." gesting that the costs of the exclusionary rule were quite low, the dissenters were in a better position to highlight the impor-

${ }^{36}$ Leon, 468 U.S. at 906 n. 6.

${ }^{57} I d$. at 917.

${ }^{58}$ Both the majority and dissent relied upon Davies, A Hard Look at What We Know (and Still Need to Learn) About the "Costs" of the Exclusionary Rule: The NIJ Study and Other Studies of "Lost" Arrests, 1983 A.B.F. RES. J. 611 (1983); U.S. General Accounting Office, Report of the Comptroller General of the United States, Impact of the Exclusionary Rule on Federal Criminal Prosecutions (1979); National Institute of Justice, The Effects of the Exclusionary Rule: A Study in California (1982); Nardulli, The Societal Cost of the Exclusionary Rule: An Empirical Assessment, 1983 A.B.F. RES. J. 585 (1983); F. FEENEY, F. DILL, AND A. WEIR, ARRESTS WITHOUT CONVICTIONS: HOW OFTEN THEY OCCUR AND WHY, NATIONAL INSTITUTE OF JUSTICE (1983).

${ }^{59}$ Leon, 468 U.S. 948. "Contrary to the claims of the rule's critics that exclusion leads to 'the release of countless guilty criminals' [citations omitted], these studies have demonstrated that federal and state prosecutors rarely drop cases because of potential search and seizure problems." The dissenters go on to point out the extremely small percentages mentioned by the majority. Id. 
tance of their preferred justification for the rule-preservation of the judicial forum-which is a rationale that does not depend on the effectiveness of the exclusionary rule as a deterrent to unconstitutional law enforcement conduct.

We need not decide here whether the majority or the dissent made the stronger case. Rather, what impresses us about Leon is the form of the inquiry and the Court's ready acceptance of relevant "social authority" to inform and guide its balancing analysis. The term "social authority" was developed by John Monahan and Laurens Walker. ${ }^{60}$ They argue that courts should, when considering the relevant social science research, treat the research in the same way that courts would treat legal precedent under common law. ${ }^{61}$ The concept of social authority has significant advantages, not the least of which is that it frees social science from the category of "fact," which would be governed by evidentiary rules, to the category of "law," which is subject to different rules and customs in judicial decision-making. Monahan and Walker suggest that social science research takes on the characteristics of fact when it is used in a case-specific way to adjudicate an issue in a settled legal context. ${ }^{62}$ In contrast, they argue that social science research should be treated more like law when it can be used to address more general issues, ${ }^{63}$ the type of issues that we conceive within the balancing rubric. It is the latter category of cases in which social science research takes on the "future-oriented generality that case precedent possesses."

An authority-based rather than fact-based notion of social science research does not require that social science be tied to the particular facts of the case presented to an appellate court. Rather, the empirical and social science research is as general as legal precedent. As a result, it is unnecessary to create new bur-

${ }^{60}$ See John Monahan \& Laurens Walker, Social Authority: Obtaining, Evaluating, and Establishing Social Science in Law, 134 U. PA. L. REV. 477, 488 (1986).

${ }^{61}$ See id. at 488.

${ }^{62}$ See id. at 491.

${ }^{63}$ See id.

${ }^{64} I d$. 
dens of proof or production with regard to the research. ${ }^{65}$ The burden of proof issues are unchanged by the introduction of social science research. So, for example, sociological research about the relationship between disadvantaged minorities and the police introduced in a case to explain the connection between flight from a police officer and guilt of crime is also relevant to an assessment of a minority individual's waiver of her right to remain silent under Miranda. Undoubtedly a reading of this research will improve anyone's commonsense judgments about human behavior-even the judgments of a Supreme Court Justice.

Leon is an excellent example of the Monahan and Walker concept of social authority at work to promote the value of transparency in adjudication. Both the majority and the dissenters are relying on the same study, but each side uses the study to promote a different viewpoint concerning the value of the exclusionary rule. It is easy to see how each side strikes the balance between liberty and order. In Leon, the interpretive choices are made clear-are transparent-because the justices set forth and discuss the empirical backdrop against which they are deciding.

It is important to note, again, that we are using the Leon decision as an illustration not for its outcome, but for its mode of legal analysis. Indeed, for our purposes here, if we had to side with anyone, we would side with Justice Blackmun. In his concurrence, Justice Blackmun wrote separately to "underscore what [he] regarde[d] as the unavoidably provisional nature" of the decision. ${ }^{66}$ Justice Blackmun noted that the Court "narrowed the scope of the exclusionary rule because of an empirical judgement that the rule has little appreciable effect in cases where officers act in objectively reasonable reliance on search warrants." ${ }^{67}$ Justice Blackmun went on to state that the provisional nature of empiricism invites testing and the prospect of change. "The logic of a decision that rests on untested predic-

${ }^{65}$ See Laurens Walker \& John Monahan, Social Facts: Scientific Methodology as Legal Precedent, 76 CAL. L. Rev. 877 (1988).

${ }^{66}$ United States v. Leon, 468 U.S 897, 927 (1984) (Blackmun, J., concurring).

${ }^{67} I d$. 
tions about police conduct demands no less." 68 We would emphasize that "provisional" is not a bad thing, but rather a virtue. It is the fulfillment of the promise of American legal realism. As Erickson and Simon suggest, "Science is by nature innovative, but the law resists innovation." 69

\section{THE DICKERSONAND WARDLOWOPINIONS}

All too often, the Supreme Court resolves criminal procedure cases without considering the social scientific or empirical research. In this respect, the 1999 Term was business as usual. Without so much as discussing or even citing in a footnote the considerable research that has been conducted on police custodial interrogation in the 1990s, the Chief Justice, writing for a seven-member majority in Dickerson $v$. United States, concluded that there was no adequate justification for overruling the requirement of Miranda warnings. Without mentioning or even referencing recent research, the Chief Justice wrote that cases decided subsequent to Miranda "have reduced the impact of the Miranda rule on legitimate law enforcement."

Writing for the Court in Wardlow as well, the Chief Justice acknowledged the empirical nature of the question-whether flight from a police officer amounted to reasonable suspicionbut stated that there were "no available empirical studies dealing with inferences drawn from suspicious behavior." sult, the Chief Justice maintained, the Court had to rely on its own "commonsense judgements about human behavior."72 In the Court's opinion, "headlong flight-wherever it occurs-is the consummate act of evasion."

These types of assertions, however, are not self-evident, common sense, or simple "facts of life." They are contested empirical claims that are hotly debated in legal and social scien-

\footnotetext{
${ }^{68}$ Id. at 928.

${ }^{69}$ Rosemary J. Erickson and Rita J. Simon, The Use of Social Science Data in SUPREME COURT DECISIONS 9 (1998).

${ }^{70}$ Dickerson v. United States, 120 S.Ct. 2326 (2000).

${ }^{71}$ Illinois v. Wardlow, 120 S. Ct. 673, 676 (2000).

${ }^{72}$ Id.

${ }^{73} \mathrm{Id}$.
} 
tific circles. There are data and studies that discuss these empirical issues. In the Dickerson context, for example, relevant research suggests that the Miranda warnings have been effective in apprising accused persons, and the general public, of their right of silence. ${ }^{74}$ Other research has revealed that police interrogators have learned to minimize the giving of Miranda warningsin certain situations, to use the Miranda procedures as a way to elicit confessions that they otherwise would not have obtained. ${ }^{75}$ This may undermine the effectiveness of the Miranda warnings in ensuring the continuous opportunity to exercise the right to silence. Clearly, this empirical research is relevant to whether the Miranda procedures are an effective means of protecting the privilege against self-incrimination.

Similarly, there is also readily available data that can help to assess the strength of the inference of guilt to be drawn from flight from a police officer. The dissenters in Wardlow cited research that called into question the emphatic nature of the majority's claim regarding flight when those evading police are members of minority groups. But, even the dissenters did not review the most comprehensive analysis of urban street stops to date, published by the New York Office of the Attorney General ("OAG Report"). ${ }^{76}$ This report easily bolsters the dissenters' claim that the racial dynamics that exist in urban areas between police and citizens makes the connection between flight from a police officer and guilt less straightforward than one might otherwise think.

Moreover, the New York OAG Report provides information

${ }^{74} \rightarrow$ Richard A. Leo, The Impact of Miranda Revisited, 86 J. CRIM. L. \& CRIMINOLOGY 621, 652-53 (1996); Paul G. Cassel \& Bret S. Hayman, Police Interrogation in the 1990s: An Empirical Study of the Effects of Miranda, 43 UCLA L. REv. 839, 889 (1996); SPECIAL Committee on Criminal Justice in a Free SOCIETY, AMerican Bar ASSOCiation, Criminal Justice IN Crisis 28 (1988); John Gruhl \& Cassia Spohn, The Supreme Court's Post-Miranda Rulings: Impact on Local Prosecutors, 3 LAW \& POL'Y Q 29 (1981); SAMUEL

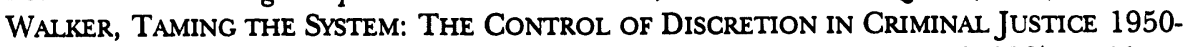
1990, at 51 (1993); Jeffrey Tobin, Viva Miranda, NEw Republic, Feb. 16, 1987, at 11.

${ }^{75}$ See Richard A. Leo and Welsh S. White, Adapting to Miranda: Modern Interrogators' Strategies for Dealing with Obstacles Posed by Miranda, 84 MINN. L. REv. 397, 413 (1999).

${ }^{76}$ See The New York City Police Department's "Stop \& Frisk" Practices: A Report to the People of the State of New York From the Office Of The Attorney General, Dec. 1, 1999, http://www.oag.state.ny.us/press/reports/stop_frisk/stop_frisk.html. 
that allows an assessment of just how reliably different categories of reasons for police stops translate into arrests. Because one of the categories of reasons for stops collected in the New York report is flight, it is possible to compare the reliability of flight from a police officer as a reason for stopping someone to a category for which the courts have historically been more confident of reliability.

We contend that this empirical research is central to properly resolving the questions presented in these constitutional criminal procedure cases. We turn to these two decisions from the 1999 Term-Dickerson v. United States and Illinois v. Wardlow-to demonstrate how the Court should have utilized social science and empirical research and how doing so would have improved the Court's constitutional decision-making. Our goal here is to demonstrate, first, that research relevant to the central legal questions presented in those cases existed, and second, that the research would have assisted the Court in understanding the constitutional landscape and resolving the cases in a more transparent way. We will begin with Dickerson $v$. United States.

\section{A. DICKERSON V. UNITED STATES}

The seeds of the Dickerson litigation were sown in 1968, two years after the Supreme Court's decision in Miranda v. Arizona, when Congress passed Title II of the Omnibus Crime Control and Safe Streets Act. Within Title II was a provision, codified at 18 U.S.C. $§ 3501$, that essentially displaced the general rule, set forth in Miranda, that any statements obtained during the course of police custodial interrogation be excluded from admission in the prosecutor's case-in-chief unless Miranda warnings were given prior to the interrogation. In the place of the Miranda procedure (warnings, waiver, and exclusion) Congress enacted a totality-of-the-circumstances test that focused on the voluntariness of the statement. Congress specified a list of circumstances that the trial court should consider, including at least three of the four Miranda warnings, whether the defendant knew the nature of the charges against him, the length of detention, and whether defense counsel was present during the 
interrogation. ${ }^{77}$ Although President Johnson signed the legislation in June $1968,{ }^{78}$ most administrations-with the exception of Attorneys General John Mitchell in 1969 and Ed Meese in 1986-ignored section $3501 .^{79}$

The question presented in Dickerson was whether the procedure for the admission of statements under 18 U.S.C. $\$ 3501$ trumps the requirement that Miranda warnings be given before interrogation. The Court did not grant certiorari on whether to reverse the two core holdings of Miranda-namely, first, that compulsion, for purposes of the Fifth Amendment, is not limited to "legal compulsion" but extends to police custodial interrogation; and second, that police custodial interrogation is inherently compulsive. ${ }^{80}$ And the Fourth Circuit did not-and, of course, could not-reverse the two core constitutional holdings of Miranda. The question presented in Dickerson, as a result, was a narrow one, focusing on the Miranda procedures (warnings, waiver, and exclusion) rather than on the larger constitutional holdings.

It was further narrowed by the fact that the principal parties to the Dickerson litigation ${ }^{81}$ - Charles Dickerson, the United States government, and Paul Cassell as court-appointed amicus curiae-as well as most legal scholars, ${ }^{82}$ agreed that the specific

${ }^{77}$ See 18 U.S.C. $\S 3501$.

${ }^{78}$ See 18 U.S.C. § 3501 History (1999); Max Frankel, President Signs Broad Crime Bill, With Objections, N.Y. TIMES, June 20, 1968, at A1, A23.

${ }^{79}$ The legislative and subsequent history of section 3501 is recounted in several articles, see e.g. Yale Kamisar, Can (Did) Congress "Overrule" Miranda?, 85 CORNELl L. REV. 883, 887-909, 925-31 (2000); Paul G. Cassell, The Statute That Time Forgot: 18 U.S.C. $\S$ 3501 and the Overhauling of Miranda, 85 IOWA L. REv. 175 (1999).

${ }^{80} \rightarrow$ Schulhofer, supra note 35 , at 436 ; Kamisar, supra note 79, at 942 ; Weisselberg, supra note 35 , at 112 .

${ }^{81}$ See Brief for the United States at *28, Dickerson v. United States, 120 S.Ct. 2326 (2000), (No. 99-5525) (available at 2000 WL 141075); Brief of Petitioner at *14, Dickerson v. United States, 120 S.Ct. 2326 (2000), (No. 99-5525) (available at $2000 \mathrm{WL}$ 142076); Brief of Court-Appointed Amicus Curiae at *23, Dickerson (No. 99-5525).

${ }^{82}$ Most scholars agree that the warnings protect the Fifth Amendment, but are not carved into stone. Stephen Schulhofer, an ardent defender of the Miranda warnings, writes, for instance: "What the Tucker passages and similar dicta mean to emphasize is not that the Miranda requirements can be altered or abandoned at will, but only that the specifics of the Miranda approach can be modified or replaced if a state provides equivalent protection to the suspect." Schulhofer, Miranda's Practical Effect, at 554; see $\iota$ Kamisar, supra note 79, at 911-13, 940- $\rightarrow$ Albert W. Alschuler, A Peculiar Privilege in Historical Perspective: The Right to Remain Silent, 94 MiCH. L. REv. 2625, 2630 n.19 (1996); Weisselberg, supra note 35, at 121-22. 
procedure set forth in Miranda was not the only procedure that would possibly satisfy constitutional requirements. The parties agreed that the Miranda warnings were intended to protect the Fifth Amendment privilege against self-incrimination, and that, in this sense, they were not themselves exclusively dictated by the Fifth Amendment. ${ }^{83}$ This followed logically from the Court's invitation in Miranda to Congress and the states to implement different safeguards. The Court had written, in a now famous passage:

It is impossible for us to foresee the potential alternatives for protecting the privilege which might be devised by Congress or the States in the exercise of their creative rule-making capacities. Therefore we cannot say that the Constitution necessarily requires adherence to any particular solution for the inherent compulsions of the interrogation process as it is presently conducted. Our decision in no way creates a constitutional straightjacket which will handicap sound efforts at reform, nor is it intended to have this effect. We encourage Congress and the States to continue their laudable search for increasingly effective ways of protecting the rights of the individual while promoting efficient enforcement of our criminal laws. However, unless we are shown other procedures which are at least as effective in apprising accused persons of their right of silence and in assuring a continuous opportunity to exercise it, the [Miranda] safeguards must be observed.

This passage-inserted by Chief Justice Earl Warren at the suggestion of Justice William Brennan ${ }^{85}$-clearly communicated that alternative measures could displace the Miranda procedures under certain specified circumstances, namely if the measures were at least as or more effective at making accused persons aware of their right to silence and assuring a continuous opportunity to invoke the right to silence.

Where the parties to the Dickerson litigation did disagree was on the even narrower question of whether the Miranda procedures were a constitutional floor or, instead, were above the floor necessary to protect the Fifth Amendment. The govern-

${ }^{83}$ See, e.g., Brief of Court-Appointed Amicus Curiae at *3, Dickerson (No. 99-5525). ("The rule was an exercise by the Court of its power to devise, in the absence of legislation, prophylactic measures that may extend beyond constitutional requirements in order to protect the underlying constitutional right.")

${ }^{84}$ Miranda, 86 S.Ct. at 1624.

${ }^{85}$ See Charles D. Weisselberg, Saving Miranda, 84 CoRnell L. REv. 109, 123-25 (1998); Yale Kamisar, supra note 79, at 883, 940. 
ment and Dickerson argued that the Miranda warnings were the minimum acceptable safeguards, and that anything less would automatically violate the Fifth Amendment. Court-appointed amicus, on the other hand, viewed the Miranda warnings as "overprotective and extraconstitutional."

In Cassell's view, the Miranda rule of automatic exclusion of un-Mirandized statements "extends beyond the Fifth Amendment's bar on actually compelled statements," is a "more sweeping, albeit prophylactic, measure," and, therefore, is not itself required by the Constitution. ${ }^{87}$ The crux of the disagreement was in amicus curiae's use of the words "more" or "extra." As amicus argued, "Congress of course has no authority to . . . abrogate a judicially devised protective measure essential to the survival of a constitutional right. But that is very different from saying that Congress likewise has no authority to modify a ruling that 'overprotects' a constitutional right, as is clearly the case with Miranda's automatic rule excluding all unwarned statements." 88

Given the specific language of the Miranda opinion, especially the now-famous passage previously quoted, as well as the fact that the Court applied the Miranda procedure to the states, it is clear that the Supreme Court in Miranda viewed the warnings as a constitutional minimum, rather than as extraconstitutional safeguards. As Yale Kamisar has argued, the stronger argument for section 3501 dates to the period its passage, and to the post-Warren Court decisions-Michigan $v$. Tucker, New York v. Quarles, and Oregon v. Elstad-in which the Court recharacterized the Miranda procedures as having less than constitutional pedigree. ${ }^{89}$ The Supreme Court in Dickerson could have held that those subsequent cases had overruled Miranda. Similarly, the Court in Dickerson could have overruled Miranda, struck a difference balance, and required different safeguards. ${ }^{90}$ Cassell's fallback position in his amicus curiae brief

${ }^{86}$ Brief of Court-Appointed Amicus Curiae, supra note 81, at *3.

${ }^{87} I d$. at $* 3, * 7-8, * 10$.

${ }^{88} I d$. at $* 12$.

${ }^{89}$ See Kamisar, supra note 79, at 936.

${ }^{90}$ See George C. Thomas III, The End of the Road for Miranda v. Arizona ?: On the History and Future of Rules for Police Interrogation, 37 AM. CRIM. L. REV. 1, 15 (2000) (arguing that the Court could have decided to rewrite the last sentence of that passage). 
called on the Court to do just that. ${ }^{91}$ But it is clear from the language of Miranda and its application to the states that Congress did not have the authority, prior to those post-3501 Supreme Court decisions, to simply disregard the express language in Miranda, restrike the balance that Miranda had struck, and declare that less protective measures were now sufficient. To do otherwise would ignore the entire concept of judicial review.

Thus, the Dickerson case raised two narrow and interrelated questions. The first question was whether the procedures in section 3501 were "at least as effective in apprising accused persons of their right of silence and in assuring the continuous opportunity to exercise it." If so, then the 3501 procedures satisfied Miranda. The second question was whether the Court should revisit the balance that it had struck in Miranda and require different safeguards.

\section{Whether the procedures in section 3501 are "at least as effective" as Miranda warmings}

The interpretive choices raised by the first question in Dickerson had already been made in Miranda. In requiring Miranda warnings, the Court effectively had balanced the interests of personal liberty from compelled self-incrimination against the efficient enforcement of the criminal law. After all, the Court in Miranda did not require the presence of counsel in custodial interrogation, nor did it prohibit all custodial interrogation outright. These outcomes would have better protected the right against compelled self-incrimination if the interests of liberty alone had determined the scope of the right. But the Court instead weighed the interests of law enforcement. It is in this sense that, as Justice O'Connor has stated, "as any reading of Miranda reveals, the decision . . . embodies a carefully crafted balance designed to fully protect both the defendant's and society's interests." ${ }^{92}$ Yale Kamisar, one of Miranda's staunchest supporters, has similarly stated that Miranda is based on "an

arguing that " $[\mathrm{t}]$ his would of course amount to overruling part of Miranda's holding, but it would stop short of overruling the case entirely.").

${ }^{91}$ See Brief of Court-Appointed Amicus Curiae, supra note 81, at *40.

${ }_{92}$ Moran v. Burbine, 475 U.S. 412, 433 n.4 (1986) (O'Connor, J., writing for six Justices). 
interpretation of the self-incrimination clause and a judgment about how to strike the appropriate balance between the needs of law enforcement and the rights of custodial suspects." ${ }^{93}$ In fact, referring to Justice O'Connor's comments in Moran $v$. Burbine, Kamisar writes that "this is the way Miranda's defenders-not its critics-have talked about the case for the past three decades." ${ }^{94}$

The Court in Miranda specifically set forth an empirical test to determine whether other procedures could displace the Miranda warnings, namely whether alternative measures were at least as effective as the Miranda warnings. The notion of "effectiveness" was defined by the Court in Miranda as "apprising accused persons of their right of silence and . . . assuring a continuous opportunity to exercise it." As a result, the first question in Dickerson raised a relatively straightforward empirical issue: is section 3501 at least as effective as the Miranda procedures? Although we do not have empirical evidence regarding the effectiveness of a post-Miranda section 3501 regime, we do have relevant research concerning the effectiveness of the Miranda warnings and can draw some inferences from that evidence.

The relevant empirical and social scientific research on police interrogation (under the existing Miranda procedures) suggests that, in virtually all observed police custodial interrogations, the police inform suspects of their Miranda rights. Richard Leo has conducted extensive field work inside the criminal investigation division of a large police department in an urban setting with a population of about 375,000 and a

${ }^{93}$ Kamisar, supra note 79, at 918; see also Yale Kamisar, The Warren Court and Criminal Justice, in THE WARREN COURT: A RETROSPECTIVE 116, 120 (B. Schwartz ed., 1996). Kamisar calls this balancing a theoretical or normative judgment, in contrast to an empirical judgment. See Kamisar, supra note 79, at 918, nn. 181, 183. In our opinion, it is instead a normative judgment that needs to be based on solid empirical evidence-and in this sense is a mixed empirical and normative decision.

${ }^{94}$ Kamisar, supra note 79, at 952; see also, Yale Kamisar, The "Police Practice" Phases of the Criminal Process and the Three Phases of the Burger Court: in THE BURGER YEARS: RIGHTS ANd Wrongs In The Supreme Court, 1969-1986 143, 150 (Herman Schwartz ed., 1987). 
minority population of about $72 \% .^{95}$ Leo sat in on 122 interrogations. Leo also reviewed the videotapes of sixty additional interrogations conducted in two separate areas with populations around $120,000 .^{96}$ Leo found that detectives provided Miranda warnings in all of the cases in which they were required (in 175 out of 182 (or $96 \%$ ) of the total cases observed). ${ }^{97}$

In a study conducted by Paul Cassell involving 173 interrogations in Salt Lake City in 1994, Cassell found only one clear case and two arguable cases of non-compliance with the requirement of Miranda warnings. ${ }^{98}$ Another study, conducted in 1981, which reviewed litigation records, similarly found few deviations from the Miranda procedures. ${ }^{99}$ The American Bar Association conducted a randomized telephone survey of over 800 judges, prosecutors and police officers, and the police officers surveyed indicated that they consistently comply with Miranda warnings. ${ }^{100}$

Accordingly, relevant evidence suggests that the Miranda procedure has resulted in near-universal notification of rights in the custodial context. Moreover, as a result of the requirement of Miranda warnings and the popular diffusion of the warnings through the media and popular culture, many people today know their Miranda rights. ${ }^{101}$ A national poll conducted in 1991 indicated that $80 \%$ of respondents knew that they have a right to remain silent if arrested. ${ }^{102}$ An earlier national poll in 1984

${ }^{95}$ See Richard A. Leo, Inside the Interrogation Room, 86 J. CRIM. L. \& CRIMINOLOGY 266, 268 (1996).

${ }_{96}$ See id. at 268, $268 \mathrm{nn} .14-15$.

$97 \rightarrow$ Richard A. Leo, The Impact of Miranda Revisited, 86 J. CRIM. L. \& CRIMINOLOGY 621, 652-53 (1996).

${ }^{98}$ See, e.g. Paul G. Cassel \& Bret S. Hayman, Police Interrogation in the 1990s: An Empirical Study of the Effects of Miranda, 43 UCLA L. REv. 839, 889 (1996) (in study of 219 arrests, involving 173 interrogations, there was only one clear case of Miranda noncompliance).

${ }^{99}$ See John Gruhl \& Cassia Spohn, The Supreme Court's Post-Miranda Rulings: Impact on Local Prosecutors, 3 LAW \& POL'Y Q 29 (1981).

${ }^{100}$ See Special Committee on Criminal Justice in a Free Society, American Bar Association, Criminal Justice in Crisis 28 (1988).

${ }^{101}$ See Leo, supra note 97, at 651; Paul Cassell, Miranda's Social Costs: An Empirical Reassessment, 90 Nw. U. L. REV. 387, 450-451 (1996).

102 See Samuel Walker, Taming the System: The Control of Discretion in Criminal Justice 1950-1990, at 51 (1993). 
found that $93 \%$ of the persons surveyed knew that they had a right to counsel if arrested. ${ }^{103}$

To be sure, proponents of section 3501 contend that police interrogators likely would continue to inform suspects of their rights under a 3501 regime. ${ }^{104}$ While some law enforcement agencies and individual interrogators may well have continued giving Miranda warnings under a section 3501 procedure, there is not a good reason to believe that compliance would be equal to the present Miranda regime, since 3501, in contrast to Miranda, does not require automatic exclusion. In other words, section 3501 does not provide an equal incentive over the longterm or over the complete range of cases for police interrogators to inform all suspects of their right to silence.

Current research also suggests that the Miranda procedures are effective, as well, in assuring the accused an opportunity to exercise their right of silence. In Richard Leo's study of 182 interrogations, approximately $75 \%$ of the suspects waived their Miranda rights in response to receiving their Miranda warnings, about $21 \%$ invoked their rights, while another $4 \%$ did not receive Miranda warnings because it was not believed that they were technically in custody for purposes of Miranda. ${ }^{105}$ Excluding the cases where Miranda was not believed to be required, $78 \%$ of the suspects waived and $22 \%$ of the suspects invoked their Miranda rights.

In Cassell's study in Salt Lake City, twenty-one suspects (or $16.3 \%$ of suspects given Miranda warnings) invoked their rights initially. ${ }^{106}$ Paul Cassell has compiled the available historical data from post-Miranda studies concerning rates of invocation of Miranda rights and, although they vary considerably, found that they average somewhere around 20\%-which is consistent with the more recent Leo and Salt Lake studies. ${ }^{107}$ Again, while there is scarce empirical evidence concerning a post-Miranda

${ }^{103}$ See Jeffrey Tobin, Viva Miranda, New REPublic, Feb. 16, 1987, at 11.

${ }^{104}$ See, e.g., Brief of Court-Appointed Amicus Curiae, Dickerson (No. 99-5525); Government Brief, Dickerson (No. 99-5525).

${ }^{105}$ See Richard A. Leo, supra note 95, at 275 tbl.2.

${ }^{106}$ See Cassell \& Hayman, supra note 98, at 860.

${ }^{107}$ See Cassell, supra note 101 at 495 and n.623. 
section 3501 regime, there is not a good reason to believe that a regime like section 3501-a regime that does not explicitly require notification of the right to silence, express waiver of the right to silence or automatic exclusion-would be equally effective in assuring the continuous opportunity to exercise the right to silence. Again, section 3501 does not give police interrogators an equal incentive to provide Miranda-type warnings to all accused persons in custody.

As an empirical matter, then, the first question is relatively straightforward. In this respect, we agree with Yale Kamisar that this empirical inquiry need not detain us for very long. As Kamisar explains:

Section 3501 does not contain a video taping or audio taping requirement, or anything else even arguably constituting an effective alternative to the Miranda safeguards. ... It is hard to see how anyone can seriously argue that the Miranda Court encouraged or invited Congress to abolish Miranda in favor of the very test the Court had explicitly and emphatically found inadequate to protect the rights of suspects.

Some commentators argue, however, that this first empirical question need not detain us at all and that we do not even need to consider any empirical evidence, since it is so clear from the legislative intent of section 3501 that Congress meant to eliminate the Miranda warnings and return to the prior, less protective Due Process test. The argument goes something like this: in Miranda, the Court held that the Due Process voluntariness test was not sufficiently effective in apprising accused persons of the right to silence and therefore required Miranda warnings as a more effective procedure. By returning to the voluntariness standard in section 3501, Congress intentionally enacted a procedure that was less effective than Miranda. Congress does not have the authority to overrule Miranda in this way.

Moreover, there is no need for empirical research since the voluntariness regime embodied in section 3501 is by definition less effective than the Miranda warnings. Even if recent studies reveal that the Miranda warnings are less effective than the Court had hoped in 1966, the section 3501 regime would still be

${ }^{108}$ Kamisar, supra n. 79 at $912-13$. 
less effective than Miranda warnings and therefore not an acceptable substitute. There is, accordingly, no need to review any empirical evidence, first because of Congress' intent and second because section 3501 is per se less effective than Miranda warnings.

The Chief Justice in Dickerson in fact articulated both of these arguments as justification for reversing the Fourth Circuit. The Chief Justice noted, first, that "Congress intended by its enactment to overrule Miranda" and held that "Congress may not legislatively supersede our decisions interpreting and applying the Constitution." ${ }^{109}$ Second, the Chief Justice wrote that section 3501 "explicitly eschews a requirement of pre-interrogation warnings" and therefore is per se no "adequate substitute for the warnings required by Miranda." 110

As to the first part of the argument, we would respond that there is no good reason to privilege Congressional intent-a nebulous conception to begin with-over the reality of contemporary police interrogation. The fact is that, in the last thirtyfive years, police practices have changed. The first question posed to us today by Dickerson-in contrast to the first question which would have been posed if Dickerson had reached the Court in 1968 or 1969 -is whether a section 3501 regime in 2000 is likely to be at least as effective as the Miranda warnings as envisaged in 1966. Surely, if there were solid contemporary evidence that, during the past thirty years, the federal courts had vigorously enforced the voluntariness standard incorporated in section 3501 to the point where it actually was more effective than the Miranda warnings, then we would have reached a different result in Dickerson. ${ }^{111}$ To be sure, there is no such

${ }^{109}$ Dickerson, 120 S.Ct. at 2332.

${ }^{110}$ Id. at 2335.

"II Several commentators have argued that the Miranda warnings have in fact had the inverse impact-namely, that Miranda may have undermined judicial scrutiny of the voluntariness of statements pursuant to the Due Process clause. George Thomas, Richard Leo and Alfredo Garcia have highlighted the fact that "the routinized Miranda ritual lulls judges into admitting confessions with little inquiry into voluntariness." George Thomas, The End of the Road at 18-21; Alfredo Garcia, Is Miranda Dead, Was It Overruled, Or Is It Irrelevant?, 10 ST. THOMAs L. REv. 461, 499-502 (1998); Richard A. Leo, From Coercion to Deception: The Changing Nature of Police Interrogation in America, 18 Crime, L. \& Soc. Change 35, 44 (1992); Richard A. Leo, Miranda and the 
evidence. But, as a matter of constitutional theory, there is no good reason to privilege authorial intent from 1968 over the empirical realities of 2000 .

With regard to the second part of the argument, we would emphasize that it rests on an empirical assumption. To be sure, an empirical assumption shared by most people, and particularly by the Court in 1966 and most members of Congress in 1968. But an empirical assumption nonetheless. That empirical assumption is that the Miranda warnings are per se more effective than the voluntariness standard. If Congress had enacted any other type of alternative procedure other than the due process test that Miranda expressly displaced, then presumably most commentators would agree that the case did raise an empirical question. If next year Congress were to enact a video-taping provision or to require the presence of counsel in custodial interrogation, then surely we would have to examine the empirical question whether video taping or the presence of counsel is likely to be as effective as the Miranda procedure. In this sense, the first question in Dickerson does raise an empirical question. An easy one, perhaps. But an empirical question nonetheless.

\section{Whether the Court should revisit the balance struck in Miranda and require a different procedural regime.}

The second question raised by Dickerson is far more challenging both as a normative and empirical matter. The second question effectively asks whether the Court should revisit the balance between the liberty and order interests that it struck when it required Miranda warnings in 1966. This question calls for a balancing-of-interests jurisprudential approach informed by the most current and reliable empirical and social science

Problem of False Confessions, in The MiRANDA Debate: LAW, JUSTICE AND POLICING 276-77 (Richard A. Leo \& George C. Thomas, III, eds., 1998). Once judges are satisfied that the suspect was informed of his rights and waived them, the subsequent voluntariness analysis may become pro forma, they suggest. The result could be that more suspects are being compelled to self-incriminate by means of police trickery and deceit that would not be condoned absent the Miranda warnings. This is a provocative and in teresting thesis that is relevant to the analysis here. It is, however, at this point extremely speculative and has not been empirically assessed. This further underscores our call for more empirical research in the criminal procedure area. 
evidence concerning the effectiveness of the Miranda warnings and their effect on the efficient enforcement of the criminal law.

In the Dickerson opinion, the Chief Justice treated this question in three short paragraphs that nowhere addressed available research on police interrogation. The Chief Justice relied primarily on the justification of stare decisis. He found no special justification to depart from the Miranda procedures, declaring that "Miranda has become embedded in routine police practice to the point where the warnings have become part of our national culture."112 In addition, the Chief Justice added-in a familiar rhetorical flourish-that "our subsequent cases have reduced the impact of the Miranda rule on legitimate law enforcement. ..."113

We contend that the Court's opinion and decision-making would have been more transparent and well reasoned-and thereby more convincing and legitimate-if the Court had considered and assessed the relevant research, and explicitly articulated its normative judgment about the propriety of the Miranda warnings in relation to the relevant social science research. There exists research that the Court should have considered and referenced in its opinion that gives some measure of the effectiveness and costs to law enforcement of the Miranda warnings. That research is relevant in deciding whether to continue requiring Miranda procedures. It informs the balancing-ofinterests analysis. And it renders more transparent the choices that the Court is making in continuing to require Miranda warnings.

a) Research regarding the effectiveness of the Miranda warnings in protecting the Fifth Amendment right against self-incrimination.

We have already reviewed relevant research that indicates that the Miranda warnings are effective in apprising accused persons, as well as the general public, of their right to silence and in assuring an opportunity to exercise that right. There is,

112 Dickerson, 120 S.Ct. at 2336.

113 Id. 
however, additional evidence that the Court should have taken into consideration.

On the one hand, in further support of the effectiveness of Miranda warnings, there is evidence that Miranda procedures have resulted in a lower frequency of police interrogation of suspects. Lower rates of police interrogation mean, naturally, a lower probability of possibly compelled self-incrimination. Paul Cassell's study of contemporary police practices in Salt Lake City shows that, of his sample of 219 suspects arrested, the police only questioned 173 , or $79 \%$ of the suspects. Twenty-one percent were not questioned. These results parallel another study, conducted in 1979, which revealed that the police in Jacksonville, Florida, did not question $18.5 \%$ of arrested burglary suspects, and that the police in San Diego, California, did not question $20.1 \%$ of such suspects. Cassell argues that preMiranda interrogation rates were much higher and that the differential may be due to the requirement of Miranda warnings. ${ }^{114}$ A reduction in the rate of interrogation of suspects, if attributable to the Miranda warnings, naturally would correspond to more protection of the right against compelled selfincrimination.

On the other hand, there is countervailing research that suggests that police interrogators have adapted to the Miranda regime and are now better able to minimize the Miranda warnings and avoid invocation of the right to silence. This research undermines the claim of Miranda's effectiveness in assuring an accused the continuous opportunity to fully exercise their right of silence. The thirty-five years since Miranda have brought numerous "refinements" in police interrogation techniques. Leading manuals in police interrogation-like Fred Inbau, John Reid and Joseph Buckley's third and newest edition of CRIMINAL INTERROGATION AND CONFESSIONS-describe some of the more successful techniques at eliciting waivers and incriminating statements. Many of the police tactics prescribed by interrogation experts are specifically aimed at increasing the level of compulsion in the interrogation room in order to make it more

${ }^{114}$ See Cassell \& Hayman, supra note 98 , at 854-58. 
likely that the suspect waive her Miranda rights. ${ }^{115}$ Many of the strategies involve psychological ploys intended to reduce Miranda invocations.

Richard Leo describes the most prevalent strategies: conditioning (creating a relaxed, friendly and concerned environment conducive to waiving Miranda rights); de-emphasizing the importance of the Miranda warnings (blending the warnings into the conversation or calling the warnings a formality); and persuasion (convincing the suspect that it is in her best interest to talk to police). ${ }^{117}$ These strategies are often deployed in what Leo refers to as a confidence game, where the police interrogator seeks to induce confidence and trust from the suspect in exchange for hope of a better future for the suspect. ${ }^{118}$ To be sure, some of these strategies are simply violations of Miranda, such as, for instance, when experts recommend against giving Miranda warnings too early in the questioning; ${ }^{119}$ but many other of these investigative strategies are not necessarily outright violations of Miranda.

Even more, Richard Leo and Welsh White have suggested that giving Miranda warnings in certain cases may actually put suspects at ease and thereby elicit confessions that would not otherwise have been obtained. The theory here is that by making suspects feel more comfortable in the interrogation setting, the increased level of comfort may decrease their guard and thereby result in more confessions. In Adapting to Miranda, Leo and White present evidence-excerpts of interrogation transcripts collected over the past twelve years-of situations where, in their opinion, the giving of Miranda warnings are actually

${ }^{115}$ See, e.g., InBaU et al., Criminal INTERROGATION AND CoNFESSIONS 29-34 (3d. ed. 1986) (describing the type of interrogation room that increases suspect's anxiety).

${ }^{116}$ See also research on the social psychology of confessions, including LAWRENCE WrightSMAN \& SAUL Kassin, Confessions IN THE CoURTROOM (1993); Saul M. Kassin \& Katherine L. Kiechel, The Social Psychology of False Confessions: Compliance, Internatization, and Confabulation, 7 PsychOL. ScI. $125(199 \stackrel{\rightarrow}{\rightarrow}$ Saul M. Kassin \& Karlyn McNall, Police Interrogations and Confessions: Communicating Promises and Threats by Pragmatic Implication, 15 LAW \& HUM. BEHAV. 233 (1991).

${ }^{117}$ See Leo, supra note 97 , at 660-65.

${ }^{118}$ See generally Richard Leo, Miranda's Revenge: Police Interrogation as a Confidence Game, 30 Law \& Society Review 259, 264-66 (1996).

${ }^{119}$ See INBAU et al., supra note 115, at 224-25 (discussing delayed warnings). 
used as a way to elicit confessions. These are situations where, in their words, "interrogators are sometimes able to present the Miranda warnings so that suspects are led to believe that waiving their Miranda rights will be to their advantage."120

As a result, some commentators suggest that the Miranda warnings may no longer exert much influence in the interrogation setting. George Thomas has scrutinized the evidence and concludes that the Miranda warnings have "largely failed" to protect suspects and control police interrogation: "guilty suspects who see no benefit in talking to the police will refuse to cooperate whether they receive Miranda warnings or not .... Guilty suspects who can be tricked into making damaging statements by the police can also be tricked into waiving their Miranda rights." 21

b) Research regarding the effect of Miranda warnings on the efficient enforcement of the criminal law.

There is also relevant research concerning the effect of the Miranda regime on law enforcement behavior. Although, again, we do not have empirical evidence regarding a post-Miranda section 3501 regime, we do have analogous evidence about the impact on law enforcement of the Miranda warnings as compared to a regime without Miranda warnings similar to section 3501. The procedure enacted in 18 U.S.C. $\$ 3501$ is practically identical to the totality-of-the-circumstances voluntariness test that the courts employed before the Miranda decision-and continue to employ today-in Due Process challenges to the admission of defendants' out-of-court statements.

Like the Due Process standard, section 3501 adopts the legal standard of voluntariness, as well as a totality-of-thecircumstances approach. Section 3501 specifically lists a number of factors that the reviewing court must consider, all of which were already reflected in the due process standard in 1966. Two of the five factors listed in section 3501 involve whether specific Miranda warnings were given. The Supreme Court and lower federal courts had held, prior to and subsequent to Miranda, that the failure to give Miranda-type warnings

\footnotetext{
${ }^{120}$ Leo \& White, supra note 75 , at 413.

${ }^{121}$ Thomas, supra note 90 , at 4 .
} 
was a relevant circumstance to be considered in the due process analysis. ${ }^{122}$ Two other factors listed in section 3501 include the time that elapsed between arrest and arraignment and whether the defendant knew of the nature of the offense. Both of these two factors - the time elapsed ${ }^{123}$ and knowledge of the nature of the offense ${ }^{124}$-were also traditionally part of the Due Process

${ }^{122}$ In Haynes v. Washington, 373 U.S. 503, 510-11 (1963), for example, the Court wrote that "'there [is no] indication in the record that prior to signing the written confession, or even thereafter, Haynes was advised by authorities of his right to remain silent, warned that his answers might be used against him, or told of his rights respecting consultation with an attorney." See also Culombe v. Connecticut, 367 U.S. 568,635 (1961) (due process precludes use of confession obtained after prolonged period of questioning and when defendant was not apprised of right to remain silent and right to an attorney); Payne v. Arkansas, 356 U.S. 560, 567 (1958) (due process violation occurred where police officers failed to advise defendant of his right to remain silent and right to counsel while holding him incommunicado for three days); Turner v. Pennsylvania, 338 U.S. 62, 65 (1949) (failure to inform defendant of right to remain silent and interrogation for five consecutive days without aid of counsel violates due process); see also cases cited in Brief for the United States, supra note 81, at *16 n.11.

${ }^{123}$ In Gallegos v. Nebraska, 342 U.S. 55, 65 (1951), for instance, the Supreme Court recognized that "prolonged detention without a charge of crime or without preliminary appearance before a magistrate" is a factor in its due process analysis. Similarly, in United States ex rel. Wade v. Jackson, 256 F.2d 7, 14 (2d Cir. 1958), the Second Circuit court observed that "“" $[\mathrm{t}]$ aking a man to the state police barracks, keeping him incommunicado for 23 hours during which he is permitted no sleep, with no food whatsoever, and only two glasses of liquid after many hours, submitting him to constant questioning despite his denials, is not only degrading and uncivilized but it is obviously coercive." The court went on to conclude that the 23-hour delay was far more than was reasonably necessary for investigation, and, therefore, that Wade's statements were involuntary. Id. at 16. See also, e.g., Turner v. Pennsylvania, 338 U.S. 62, 64 (1949) (delay in preliminary hearing considered as factor in due process analysis); Pugh v. State of North Carolina, 238 F. Supp. 721, 724 (E.D.N.C. 1965) (due process violated where defendant held in custody for ten days prior to arraignment without the opportunity to consult with counsel); see also cases cited in Brief for the United States, supra note 81 , at *17 n.12.

${ }^{124}$ There was much confusion in Dickerson and in related academic debate as to whether this factor was part of the Due Process analysis pre- or post-Miranda. See Brief for the United States, supra note 81 , at *17-18, citing Harris v. South Carolina, 338 U.S. 68 (1949) (referring to this factor, the Court suggested the factor insignificant in the voluntariness inquiry); see also Brief of Court-Appointed Amicus Curiae, supra note 81 , at *33 (arguing that, even "under current law, no such inquiry is relevant in order to assess the voluntariness of a suspect's confession; that the Harris case was merely a plurality opinion; and that the government could not come up with one majority opinion); Thomas, supra note 24, at 17 (suggesting that because knowledge is not required for waiver under Colorado v. Spring, "Section 3501 actually gives defendants more than Miranda has been held to require); Kamisar, supra note 79, at 934 and note 262. Careful research, however, does reveal that courts did consider it as a 
analysis. The last factor is whether counsel was present during the interrogation, and that factor was also considered by the Court prior to $1966 .{ }^{125}$ As Kamisar has correctly stated, section 3501 "adds nothing to the pre-Miranda voluntariness test." ${ }^{126}$ As a result, we can use as an empirical proxy for section 3501 the voluntariness regime that pre-dated Miranda and that still exists today.

From this perspective, the best evidence of the potential effect of Miranda warnings on law enforcement is the thorough exchange between Paul Cassell and Steve Schulhofer in the Northwestern University Law Review on the set of empirical studies concerning the impact of Miranda around the time of its passage-what are known as the Miranda impact studies. ${ }^{127}$ In Miranda's Social Cost: An Empirical Reassessment, Paul Cassell compiles, reviews and assesses eleven "before-and-after" studies that were conducted around the time of the Miranda decision. ${ }^{128}$ These studies were originally designed to assess the change in the confession rate in various jurisdictions. The distinct advantage of these studies, as Cassell notes, is that "studies in a single jurisdiction automatically hold constant a variety of factors that might otherwise confound comparative analysis." ${ }^{29}$ Cassell credits eight of the ten studies that found a decline in confessions after Miranda, and excludes the one study from Los Ange-

factor in the totality of the circumstances analysis before Miranda. In Turner v. Pennsylvania, 338 U.S. 62, 63 (1949), for instance, the Supreme Court considered as a factor in its Due Process analysis the fact that the police "did not tell the petitioner why he was being arrested." See, e.g., United States ex rel. Kemp v. Pate, 240 F. Supp. 696, 705-706 (N.D. Ill. 1965) (due process violated where, inter alia, defendant was not informed of the charge against him during interrogation).

${ }^{125}$ In Gallegos v. Colorado, 370 U.S. 49, 54 (1962), a case involving a 14-year-old boy, the Court noted that "the failure to see to it that he had the advice of a lawyer or a friend" was a factor that made his confession involuntary and in violation of the Due Process clause. See, e.g., Fikes v. Alabama, 352 U.S. 191, 197 (1957) (defendant was denied Due Process where his confession was obtained after lengthy questioning in the absence of counsel); Blackburn v. Alabama, 361 U.S. 199, 207-208 (1960) (confession obtained, inter alia, in the absence of counsel, violated due process); Lisenba v. California, 314 U.S. 219, 240 (1941) (depriving suspect of advice of counsel is relevant when determining whether confession is voluntarily obtained); see also cases cited in Brief for the United States, supra note 81 , at *15, n.10.

${ }^{126}$ Kamisar, supra note 79, at 930; see id. at 930-936 (reviewing the law of preMiranda voluntariness in light of section 3501's list of factors to consider).

${ }^{127}$ See Cassell, supra note 101; Schulhofer, supra note 82.

${ }^{128}$ See Cassell, supra note 101, at 395-416.

${ }^{129} I d$. at 395. 
les that found an increase in confessions after Miranda. ${ }^{130}$ Cassell factors the eight studies together and concludes that there was about a $16.1 \%$ decline in confessions as a result of Miranda. ${ }^{131}$

Stephen Schulhofer reexamines the same studies, and reaches a slightly different conclusion about the average decline in confessions in the wake of the Court's Miranda decision. ${ }^{132}$ Reassessing the evidence, Schulhofer concludes that it supports, at most, a claim that Miranda resulted in between $6.4 \%$ and $9.7 \%$ reduction in confessions in the immediate post-Miranda period, depending on whether to include the Los Angeles study (which involved a regime with some warnings prior to Miranda). The differences between Cassell and Schulhofer are summarized in the following table:

TABLE 1: "BEFORE-AND-AFTER" STUDIES ON CONFESSION RATES

\begin{tabular}{|l|l|l|}
\hline STUDY & CASSEL & SCHULHOFER \\
\hline Pittsburgh, PA & $-18.6 \%$ & $-16.2 \%$ \\
\hline New York County & $-34.5 \%$ & Exclude as unreliable \\
\hline Philadelphia, PA & $-24.6 \%$ & $\begin{array}{l}-13.8 \% \text { (perhaps un- } \\
\text { derestimating) }\end{array}$ \\
\hline Seaside City, CA & $-2.0 \%$ & $\begin{array}{l}0 \% \text { (perhaps underes- } \\
\text { timating) }\end{array}$ \\
\hline New Haven, CT & $-16.0 \%$ & $-12.3 \%$ \\
\hline Washington, DC & Exclude as unreliable & Exclude as unreliable \\
\hline New Orleans, LA & $-11.8 \%$ & Exclude as unreliable \\
\hline Kansas City, KA & $-6.0 \%$ & $-6.0 \%$ \\
\hline Kings County, NY & $-15.5 \%$ & Exclude as unreliable \\
\hline Chicago, IL & Exclude as unreliable & Exclude as unreliable \\
\hline Los Angeles, CA & Exclude as unreliable & $\begin{array}{l}+9.8 \% \text { (but some warn- } \\
\text { ings given) }\end{array}$ \\
\hline AVERAGE & $-16.1 \%$ & $\begin{array}{l}-9.7 \% \text { (excluding LA) } \\
\text { or -6.4\% (including } \\
\text { LA) }\end{array}$ \\
\hline
\end{tabular}

${ }^{130}$ See id. at 417.

${ }^{131}$ See id.

${ }^{132}$ See Schulhofer, supra note 82, at 516-39; see also Leo, supra note 97, at 632-52 (reviewing and assessing most of these before-and-after studies); George C. Thomas III, Is Miranda a Real-World Failure? A Plea for More (and Better) Empirical Evidence, 43 UCLA L. REV. 821, 826-31 (1996) (reviewing and assessing several of the studies). 
On the basis of two other adjustments-the greater effect of Miranda in larger cities, and the evidence of a pre-Miranda declining trend in confessions-Schulhofer suggests that the reduction in confessions may in fact have been between $5.8 \%$ and a low of $4.1 \% .^{133}$

What the Cassell-Schulhofer exchange suggests is that the implementation of the Miranda procedure in 1966 against the backdrop of the Due Process procedure may have resulted in an average reduction in confessions of between a high of $16.1 \%$ (Cassell's findings) and a low of $4.1 \%$ (Schulhofer's lowest finding). ${ }^{134}$ Although many factors may account for changing rates of confessions, given the time frame of the studies, it is likely that a substantial portion of this change in 1966-67 was due to the requirement of Miranda warnings.

Based on his review of the before-and-after studies and an estimate that confessions are needed in $24 \%$ of confession cases, Paul Cassell argues that the Miranda warnings resulted in lost cases on average against $3.8 \%$ of criminal suspects in the period immediately following Miranda. ${ }^{135}$ If that rate were applied to

${ }^{133}$ See Schulhofer, supra note 82 , at 539-41, 545. Richard Leo also reviewed and assessed these early Miranda impact studies, and he concluded inter alia that suspects continued to provide detectives with confessions and incriminating statements [in the years 1966-69], though in some instances at a lower rate than prior to Miranda." Leo, supra note 97 , at 645 .

${ }^{134}$ Cassell also conducted his own more contemporary study of police interrogation practices in Salt Lake County, Utah, but that study seems inconclusive in this context because it does not have a proper before comparison. From his study, Cassell found that $42.2 \%$ of interrogated suspects gave incriminating statements; however, Cassell did not have a reliable figure for pre-Miranda confession rates for that jurisdiction. See Cassell \& Hayman, supra note 98, at 871-72. George Thomas reexamined Cassell's data and put the number at $54 \%$. See George C. Thomas III, Plain Talk About the Miranda Empirical Debate: A "Steady-State" Theory of Confessions, 43 UCLA L. REV. 933, 935-36, 946-53 (1996). Thomas argued that Cassell had improperly excluded from his collection of incriminating statements, first, confessions that he considered to be volunteered, and second statements that were useful to the police (of the type "denial with explanation"). Cassell estimated a pre-Miranda confession rate of 55-60\% and elsewhere has reported pre-Miranda confession rates ranging from $21.5 \%$ to $68.9 \%$, so the Salt Lake County study may reflect, at most, a mid- to low-range confession rate with no reliable comparative measure of earlier confession rates. See Cassell, supra note 101 , at 418 tbl.1.

${ }^{135}$ See Cassell, supra note 101 , at 438. 
current crime figures, Cassell argues, it would translate into the loss of about 28,000 arrests for serious crimes of violence, 79,000 arrests for property crimes, and almost the same number of cases being disposed of on terms more favorable for defendants. $^{136}$

Schulhofer's assessment, naturally, is lower. As indicated earlier, his estimate of lost confessions, based on the before-andafter studies, including all adjustments, is between a high of $5.8 \%$ and a low of $4.1 \%{ }^{137}$ His estimate of the necessity rate for confessions is $19 \%$, rather than $24 \% .^{138}$ That results in an estimated average loss of convictions between $1.1 \%$ and $0.78 \%$ in the immediate post-Miranda period. ${ }^{139}$ Accordingly, using the Miranda impact studies, the Miranda warnings resulted in a loss of cases against criminal suspects of between a high of $3.8 \%$ and a low of $0.78 \%$ in the immediate aftermath of Miranda. ${ }^{140}$

${ }^{136}$ See id. at 484.

${ }^{137}$ See Schulhofer, supra note 82 at 545.

${ }^{138}$ See id.

${ }^{139}$ See id.

${ }^{140}$ Paul Cassell has also tried to quantify the effect of Miranda on law enforcement by studying crime clearance rates. First, Cassell studied the trend in clearance rates for the four-year period following Miranda. He found that, whereas clearance rates were relatively steady around $60 \%$ from 1950 to 1965, the rate of clearance dropped consistently during the four years after Miranda, and then plateaued at about $45 \%$ after that. Cassell argues that Miranda accounts for that change. Paul G. Cassell, All Benefits, No Costs: The Grand Illusion of Miranda's Defenders, 90 Nw. U. L. REV. 1084 (1996). Stephen Schulhofer, however, has demonstrated that the drop closely tracks the decline in the capacity of law enforcement to clear crimes. When the data is adjusted to reflect that decline, the data actually show that the number of crimes cleared per officer rose steadily during the period. Stephen J. Schulhofer, Miranda and Clearance Rates, 91 Nw. U. L. REv. 278, 283-84, 286-87 (1996). Cassell subsequently revisited his clearance rate study, and, with a colleague, Richard Fowles, used regression analysis on the data. Cassell and Fowles found that, holding other variables constant, the Miranda warnings-or more appropriately, the year 1966-correlated with reduced clearance rates for property crimes, robbery and total violent crimes, but not for murder, rape or assault. According to Cassell and Fowles, the Miranda warnings caused a $6.7 \%$ drop in the clearance rate for total violent crimes, and a $2.3 \%$ drop in the clearance rate for total property crim $\rightarrow$ Paul G. Cassell \& Richard Fowles, Handcuffing the Cops? A Thirty-Year Perspective on Miranda's Harmful Effects on Law Enforcement, 50 STAN. L. REV. 1055, 1086-88 (1998). John Donohue at Stanford University has replicated and reexamined, with slightly different statistical methods, the data. Donohue concluded that, although there was a statistically significant effect with regard to larceny and total violent crimes, there was none for other property crimes or for the individual crimes that make up the category of total violent crimes (murder, 
To be sure, these rates may not apply thirty-five years later. There have been significant changes. The Miranda warnings have become part of our cultural understanding and are certainly more well known by the average person today than they were thirty-five years ago. Police interrogators also have learned how to give Miranda warnings without alarming suspects. Leo and White argue, in fact, that because of new police techniques that minimize the Miranda warnings, assessments that seek to quantify the costs of Miranda in terms of lost confessions or lost cases should be dismissed as insignificant. ${ }^{141}$ Both of these changes-increased general awareness and modified police practices-would suggest that the Miranda warnings may have a smaller effect on law enforcement today than the Miranda impact studies suggest. But, these studies do give us an idea of the potential impact of the Miranda warnings on law enforcement behavior.

There is other evidence that addresses the issue of law enforcement efficiency. For example, there is some evidence that law enforcement officers believe the Miranda warnings have not impeded law enforcement. ${ }^{142}$ In the wake of former Attorney General Ed Meese's call in 1986 to overrule Miranda, the American Bar Association conducted hearings in three cities and a randomized telephone survey. The ABA Report concluded that "[a] very strong majority of those surveyed prosecutors, judges, and police officers agree that compliance with Miranda does not present serious problems for law enforcement." 143

robbery, rape, and assault). Donohue also challenged Cassell for failing to control for unquantifiable variables, including, for instance, legal changes unrelated to Miranda and changes in police reporting of crime. John J. Donohue, III, Did Miranda Diminish Police Effectiveness?, 50 Stan. L. Rev. 1147 (1998); see, also, Weisselberg, supra note 35, at 175-76; Leo \& White, supra note 75, at 400 n.11. Because Cassell's clearance studies do not account for the other significant changes in constitutional criminal procedure that occurred in the mid-1960s, we do not believe that the research is reliable on the question of Miranda's effect on law enforcement.

${ }^{141}$ See LEO \& WHITE, supra note 75, at 471.

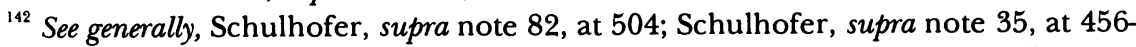
57; Leo \& White, supra note 75, at 402; Weisselberg, supra note 35, at 165 n.285.

${ }^{143}$ A.B.A. Special Comm. On Crim. Just. in a Free Society, Crim. JuSt. IN Crisis 12, 28 (1988). 
An earlier survey conducted in 1972 in southern Illinois and western Massachusetts of sixty-seven law enforcement supervisors, including police chiefs, sheriffs, police barracks' commanders and a troop commander, revealed similar results. Overall, "the officers were extremely favorable toward . . . the Miranda warnings. . . ."144 All but a couple of the Illinois chiefs and sheriffs reacted positively. In Massachusetts, the overwhelming number was favorable. ${ }^{145}$

On the other hand, Cassell and others argue that law enforcement officers generally view the Miranda warnings as significantly hampering law enforcement. ${ }^{146}$ Cassell points to the numerous amicus briefs filed by law enforcement organizations in support of the Fourth Circuit decision in Dickerson, as well as in the earlier case of Withrow. ${ }^{147}$ Of course, amicus briefs are often solicited by the parties to the litigation. With the exception of an unpublished and somewhat ambiguous 1987 telephone survey, though, most of the studies that Cassell refers to date from the $1966-70$ period. ${ }^{148}$

It has also been argued that Miranda enhances efficient law enforcement because it requires police officers to rely more on crime scene evidence and testimonial evidence, rather than confessions. In the $\mathrm{ABA}$ survey, for example, several judge respondents indicated that the Miranda decision had helped to professionalize and educate the police. ${ }^{149}$ Richard Leo concluded from his study of 182 interrogations that the Miranda warnings have "increased the level of professionalism among police officers and detectives." 150

Where does this evidence leave us? We think that a fair assessment of the empirical evidence suggests that the requirement that Miranda warnings be given resulted in some loss of cases against suspects, however slight, in the immediate after-

${ }^{144}$ Stephen L. Wasby, Small Town Police and the Supreme Court: Hearing the WORD 89 (1976).

${ }^{145}$ See id. at 89-90.

${ }^{146}$ See Brief of Court-Appointed Amicus Curiae, supra note 81, at *24-25; see also Cassell, supra note 176, at 1106-1110.

${ }^{147}$ See Brief of Court-Appointed Amicus Curiae, supra note 81, at *24-25.

${ }^{148}$ See Cassell, supra note 140, at 1107-1108.

${ }^{149}$ See ABA, supra note 143 , at $30-31$.

${ }^{150}$ Leo, supra note 97 , at 668-71. 
math of Miranda. Had the methodologies of the studies been entirely flawed, as some suggest, then Stephen Schulhofer would have excluded those studies from his re-analysis. The number is probably small, in the low single digits, less than $3.8 \%$. But there was probably some effect, however slight, on law enforcement. In this respect, we agree with Leo's early assessment of the Miranda impact literature: "suspects continued to provide detectives with confessions and incriminating statements (in the years 1966-69), though in some instances at a lower rate than prior to Miranda." We also agree with Leo and others that the passage of time has probably further eroded the impact. So the differential might be extremely small today. And there may be some cases where the Miranda procedures have actually helped obtain confessions that would not otherwise have been obtained.

In sum, relevant research suggests that the Miranda warnings-and their dissemination in popular culture-have resulted in increased public awareness of the right to remain silent and have been effective in notifying accused persons of that right. The overall effectiveness of Miranda at protecting accused persons from compelled incrimination has been somewhat undermined by recent developments in interrogation techniques. The Miranda warnings probably have some negative impact on law enforcement and result possibly in the loss of cases against suspects in a range between a small fraction of one percent and two or three percent of cases. From a normative perspective, we would contend, in light of the relevant research, that the balance of liberty and order favors the continued use of Miranda warnings.

What is more important than our own assessment of the evidence and normative balancing, though, is the fact that all of these studies-the Leo studies, the Cassell-Schulhofer debate, and all the other debates that they have spawned-are published material. The studies go over the points of disagreement in minute detail. Any court interested in forming its own opinion on the matter need only read the articles and assess the arguments about the validity of the different studies. The articles explain why certain studies are reliable and others not. For ex-

${ }^{151}$ LEO, supra note 97 , at 645 (Leo is, however, skeptical that these studies reveal anything due to their methodological flaws); see id. at 647-48. 
ample, one of the points of disagreement in the CassellSchulhofer debate is whether to include the New Orleans study. Schulhofer argues that the New Orleans study should be excluded because the before portion of the before-and-after study was based on a rough ballpark estimate by the police department that self-incriminating statements were made in about $40 \%$ of the arrests. ${ }^{152}$ Anyone reading the exchange should be able to make his or her own informed decision as to whether to include the study or not.

Again, our purpose here is not to resolve the question for the Court. It is instead to point the Court to empirical evidence from which it could have decided Dickerson, and suggest that the case should have turned on an evaluation of the social scientific evidence. It is to highlight the relevance of the empirical evidence and suggest that the Court's decision would have been better reasoned-and more transparent, more open to criticism-if the Court had addressed the research. In other words, the Court, we suggest, should have taken a position on whether a 3.8\% (or lower) loss of cases does or does not call for reevaluating the Miranda procedures. By specifically addressing those kind of empirical issues, the Court would be making its normative decisions far more transparent. In this sense, we agree with Leo and White. "In order to determine whether Miranda's warnings and waiver requirement provide an adequate constitutional safeguard, society needs to decide the extent to which law enforcement officers interrogating criminal suspects should be restrained, and the extent to which individuals subjected to such interrogation should be protected."153

\section{B. ILLINOIS V. WARDLOW}

While there were no Fourth Amendment cases on the Court's docket this term that received the kind of attention showered (deservedly) on Dickerson, there were cases, such as $\mathrm{Il}$ linois v. Wardlow ${ }^{154}$ and J.L. v. Florida, ${ }^{155}$ that illustrate well the

\footnotetext{
${ }^{152} \rightarrow$ Schulhofer, supra note 35.

${ }^{153}$ Leo \& White, supra note 75 , at 464.

154120 S. Ct. 673 (2000).

${ }^{155} 120$ S. Ct. 1375 (2000).
} 
need for increased attention to social science research. Here, we will focus on Illinois $v$. Wardlow, where the Court was asked to determine whether a police officer's stop of a suspect, after he fled upon seeing several police cruisers patrolling an area known for heavy narcotics trafficking, violated the Fourth Amendment to the Constitution. The Court, in a 5-to-4 decision, decided that the stop was constitutional, and reversed the Illinois Supreme Court's decision to the contrary.

What was unique about this particular case was that both the petitioner and the respondent asked the Court to adopt bright-line rules in order to determine the scope of Fourth Amendment rights in the context presented to the Court. The State of Illinois asked the Court to create a bright-line rule that fleeing from police officers always raises reasonable suspicion that crime is afoot. Wardlow asked the Court to decide that flight from police officers alone could never reasonably raise these suspicions.

The Supreme Court declined to adopt either side's proffered presumption; instead, the Court cleaved to its well-worn totality-of-the-circumstances test. Through an application of that test, the Court decided that flight from an identified police officer in an area known for heavy narcotics sales constituted reasonable suspicion. Whether or not the Court's conclusion is correct is clearly open to debate. The Court itself split 5-to-4 over the issues presented in Wardlow. We would like to focus here on how the Court reached this conclusion. In the process we hope to demonstrate how the Court's greater use of relevant social science in the course of articulating the scope of Fourth Amendment protection would have made the Court's decision better and more transparent.

The Wardlow case required the Court to apply the analysis it had first articulated in Terry $v$. Ohio, ${ }^{156}$ another paradigmatic example of the Court's use of a balancing-of-interests jurisprudential approach. In Terry, the Court interpreted the Fourth Amendment by balancing individual interests in liberty (privacy,

${ }^{156} 392$ U.S. 1 (1968). 
property, and autonomy) ${ }^{157}$ against societal interests in safety (which include, of course, the stopped-and-searched person's interests). The Court departed from its then long-time insistence that police interventions, searches, and seizures, be justified by the level of particularized suspicion known as probable cause. ${ }^{158}$ The Court instead determined, focusing on the Reasonableness Clause of the Fourth Amendment, that a rather common police practice of the time, ${ }^{159}$ a protective pat-down of a stopped person's clothing that fell short of a full-blown search, need only be justified by reasonable, articulable suspicion that criminal activity was afoot and that the person with whom the officer is dealing may be armed and dangerous. ${ }^{160}$ In so doing the Court avoided siding with either the suspect, Terry, who argued that all searches, even the somewhat limited pat-down presented in the case, must be justified by probable cause, or the State of Ohio, which argued that because the pat-down was not a search at all the Fourth Amendment was not implicated by the frisk.

The Court's decision in Terry reflects a conception of proportionality. ${ }^{161}$ Since a pat-down is less intrusive than a fullblown search and since an investigatory stop is less intrusive than a full-blown arrest, then one might conclude that these lesser intrusions may be justified by less evidence than more serious intrusions. This reasoning, of course, is not a foregone conclusion. ${ }^{162}$ Although the Terry Court departed from the

${ }^{157}$ See Christopher Slobogin, Let's Not Bury Terry: A Call for the Rejuvenation of the Proportionality Principle, 72 ST. JOHN's L. REv. 1053, 1057 (1998).

${ }^{158}$ See Terry, 392 U.S. at 27.

${ }^{159}$ See Wayne R. LaFave, Detention for Investigation by the Police: An Analysis of Current Practices, 1962 WASH. U. L. Q. 331, 335-36 (explaining the stop and frisk procedure observed during a 1956-57 study of the actual practices of police, which was sponsored by the American Bar Foundation).

${ }^{160}$ See Terry, 392 U.S. at 30. Justice Warren's majority opinion said very little about stops that accompany or are antecedent to frisks, but Justice Harlan in concurrence emphasized that the frisk in the case depended upon the reasonableness of the accompanying stop, and that the right to frisk must be automatic "if the reason for the stop is, as here, an articulable suspicion of a crime of violence." Id. at 33.

${ }^{161}$ See, e.g., Slobogin, supra note 157, at 1053; see also Christopher Slobogin, The World Without a Fourth Amendment, 39 UCLA L. REV. 1 (1991).

${ }^{162}$ See Terry, 392 U.S. at 36 (Douglas, J., dissenting) (arguing that that frisks should be justified by probable cause). 
more stringent probable cause requirement to justify a "stop and frisk," the Court forthrightly acknowledged that a pat-down search of a citizen's body

is a serious intrusion upon the sanctity of the person, which may inflict great indignity and arouse strong resentment, and it is not to be undertaken lightly. . . . Even a limited search of the outer clothing for weapons constitutes a severe, though brief, intrusion upon cherished personal security, and it must surely be an annoying, frightening and perhaps humiliating experience.

Yet, the Court declined to find that this demanded a more stringent justificatory standard.

The Court's conclusion is consistent with balancing of interests. If we assume that people generally prefer to be more rather than less safe, and if we also assume that people prefer less rather than more State intrusion into their personal liberty, then the achievement of the highest level of safety through the least intrusive means is ideal. Requiring police to justify less intrusive police actions (such as stops) with the same level of evidence as more intrusive police actions (such as arrests) provides law enforcers with little incentive to prefer the former over the latter.

But, the ideal seems to express a societal preference for less intrusive police actions-especially if a less intrusive action can achieve the same or higher level of safety as an action more intrusive of an individual's rights. Allowing police to justify stops and frisks with less evidence than is required for arrests and full searches implicitly encourages police officers to prefer these lesser intrusive actions over more serious ones. One difficulty, though, is that we might expect that a lesser justificatory standard for lesser intrusions would encourage a greater number of these less intrusive actions compared to the number of more intrusive actions, such as arrests, that the police would otherwise engage in when held to the higher justificatory standard for these more intrusive actions. Is this state of affairs consistent with the ideal of producing the highest level of safety possible with the least amount of intrusion? That depends on how one

${ }^{163} I d$. at $17,24-25$. 
thinks about the trade off between a higher number of less intrusive actions and a lower number of more intrusive ones in relation to the societal goal of promoting a certain level of safety. The Court, through Terry and its progeny, seems to have endorsed the view that more, broad, prophylactic law enforcement strategies may well be preferable to fewer, deeper, reactive ones. ${ }^{164}$

Thus, Terry's reasonableness approach ultimately depends on social policy analysis, including consideration of law enforcement needs, police and public safety, and social realities such as race relations between the police and the policed in disadvantaged neighborhoods. We believe, as we stated earlier, that the focus on policy is the strength of the balancing test. However, it is clear that such a focus can be a weakness - particularly if judges are not well informed about the social and political realities on which the contours of these rights depend. When they are not suitably informed, the reasonableness analysis allows judges simply to promote their own ideological agenda without that agenda being readily exposed. We do not believe, as some critics of the reasonableness approach do, that the approach more easily allows judicial decision makers to impose their own ideological views on a case. But, the reasonableness approach may make it easier for decision makers to hide their decision-making process through hand waving. It is this aspect of balancing, not the analysis itself, that ought to be avoided. We believe that it can be limited, if not avoided, through a greater emphasis on social science. Informed pragmatism, rather than increased formalism, is our prescription. With this background established, we return to an analysis of Wardlow.

${ }^{164}$ Former police officer James Fyfe, in a recent symposium on Terry $v$. Ohio, recounts the practices of the elite Los Angeles Police Department's Special Investigation Section (SIS). He explains that SIS refrains from intervening in situations that are merely suspicious. Instead, SIS surveils people planning crime and observes them while they commit crimes. This practice results in the deaths of suspects "about one for every 25 arrested" and the presentation of very strong cases against those who survive. It also violates the police obligation to protect life; police stand by as terrorized victims are robbed and brutalized. See James J. Fyfe, Terry: A[n Ex-] Cop's View, 72 ST. JOHN's L. REV. 1231, 1242 (1998). 
If an individual flees after seeing several identified police officers in a high crime areas, does such conduct lead a police officer to be reasonably suspicious that crime is afoot? Courts commonly consider the assertion that the police observed the suspect in a high-crime area before making a stop in determining whether a stop is justified-an indication that police officers may reasonably rely on such information in determining whether to stop a suspect. ${ }^{165}$ But, the Supreme Court has clearly said that presence in a high-crime area alone is not sufficient to justify a stop of a suspect. ${ }^{166}$ In Wardlow, the additional factor motivating the police to act was the fact that the suspect ran. Thus, at the heart of Wardlow is the degree of suspicion that attaches to a person's flight. Specifically, the case turns on how reliably flight indicates guilt.

If we knew that crime was indeed afoot in the vast majority of cases in which police stopped individuals on the street after such individuals had run away from them, then we would likely be much less concerned about the intrusion on individual liberty that takes place during the stop. We would conclude that this category of information is a good reason ex ante for police action, not only because the category of information seems to reliably indicate guilt of crime, but also because the particular criterion satisfied by the category of information-how reliably the information indicates that crime is afoot-is a legitimate explanation for police action. ${ }^{167}$

${ }^{165}$ See Wardlow, 120 S.Ct. 673, 676 ("[W]e have previously noted the fact that the stop occurred in a 'high crime area' [is] among the relevant contextual considerations in a Terry analysis") (citing Adams v. Williams, 407 U.S. 143, 144, (1972)); see also Ex parte Tucker, 667 So.2d 1339 (Ala. 1995); Commonwealth v. Cheek, 597 N.E.2d 1029 (Mass. 1992); WAYNe R. LAFAVE, SEARCH AND SEIZURE: A TREATISE ON THE FOURTH AMENDMENT 189 (3d ed. 1996) (location "is itself a highly relevant consideration).

${ }^{166}$ See Brown v. Texas, 443 U.S. 47 (1979) ("The fact that appellant was in a neighborhood frequented by drug users, standing alone, is not a basis for concluding that appellant himself was engaged in criminal conduct.")

${ }^{167}$ Note, however, that this analysis focuses on what are good reasons for police action. We might also think that police action is justified simply when the reasons for action are not bad ones. So randomized stops of individuals at sobriety checkpoints may be acceptable not so much because police have a good reason for stopping any 
The difficulty, though, is that the Supreme Court has never used exact proportions to explain the level of certainty a police officer must possess under the reasonableness approach. ${ }^{168}$ Despite the Court's relunctance to discuss the level of certainty probabilistically, there is evidence that decision-makers assess the level of evidence that justifies different police actions in implicit probabilistic terms. For example, in one study, 96 out of 166 federal judges surveyed indicated a belief that the reasonable suspicion standard requires $40 \%$ certainty or less that evidence of crime would be found by an officer after a stop. ${ }^{169}$ In the same study, $25 \%$ of the judges indicated that $50 \%$ certainty was necessary for reasonable suspicion, while another $19 \%$ indicated that $60 \%$ certainty or more was necessary. ${ }^{170}$ This empirical evidence makes it quite clear that Fourth Amendment jurisprudence leaves open just how much liberty should be circumscribed.

To put this another way, the ultimate question in Wardlow was: how good an indicator of guilt does flight from police have to be? The answer to this question clearly can be informed by social science research. Indeed, the Wardlow Court all but begged for this information. During oral arguments in the case, one Justice asked the Cook County State's Attorney whether there was any empirical evidence that supported the inference

particular person, but, rather, because we are confident that there is no bad reason for stopping the particular car.

${ }^{168}$ In Wardlow, the Court said a police officer can be less certain that crime is afoot than she would have to be were she effecting an arrest. Wardlow, $120 \mathrm{~S}$. Ct. at 677. Rather than emphasizing a particular quantum of evidence necessary to justify a stop under the reasonable suspicion standard, the Court has emphasized the factual basis for the stop by requiring an officer to review all those factors that motivated him to stop the suspect. See Michigan v. Summers, 452 U.S. 692, 703 (1981) where the Court stated:

it is also appropriate to consider the nature of the articuable and individualized suspicion on which the police base the detention of the occupant of a home subject to a search warrant. ... The connection of an occupant to that home gives the police officer an easily identifiable and certain basis for determining that suspicion of criminal activity justified a detention of that occupant.

${ }^{169}$ See C.M.A. McCauliff, Burdens of Proof: Degrees of Belief, Quanta of Evidence, or Constitutional Guarantees? 35 VAND. L. REV. 1293, 1327 tbl. 3 (1982).

${ }^{170}$ See id. 
that individuals who flee from the police have something to hide. ${ }^{171}$ In response, the State's Attorney pointed to wisdom from centuries-old common-law legal scholars claiming that it was "natural" for "criminals to flee." Another Justice asked about available evidence concerning racial differences in reasons for flight from the police, apparently reasoning that a bright line requiring the inference of suspicion in cases of flight would be inappropriate if it could be shown that different groups of people systematically responded differently to the presence of police in ways that called into question the correlation between flight and guilt. ${ }^{173}$ In response to this very central

${ }^{171}$ See Illinois v. Wardlow, No. 98-1036, 1999 WL 1034479, at *11-13 (U.S. Nov. 2, 1999) (oral argument):

QUESTION: Mr. Devine, there's been a lot of talk about my experience, your experience. Is there any evidence, apart from intuition, that people who have something to hide run? Justice Souter asked the question about how many innocent people are in jeopardy. Is there any empirical evidence at all to back up this intuition that people don't run unless they have something to hide?

MR. DEVINE: Well, Your Honor, we have the entire history of this country with the commentators and the cases that have-

\section{QUESTION: You have this case for starters. Right?}

MR. DEVINE: Well, absolutely, Your Honor. You have after the stop, a weapon with five live rounds in it was found on Mr. Wardlow.

QUESTION: Well, we have this case, but how many on the other side where this practice is followed? How many innocent people get stopped because they sped away?

MR. DEVINE: Well, again, Your Honor, based on my-my view of it as a prosecutor for a number of years, I don't believe it occurs that often. But what we are talking about-

\section{QUESTION: But we don't have any empirical studies of this, do we?}

MR. DEVINE: We don't have any to submit, Your Honor. We have the history of this country, how flight has been looked at over the course of the history of this country.

QUESTION: And that-that's-some of those cases, at least, involve flight after an accusation, after a charge.

${ }^{172}$ See id. at *5.

${ }^{178}$ See id. at *13:

QUESTION: What do you-what do you say about the argument that-well, there are some neighborhoods, high crime neighborhoods in particular, where people are afraid of the police? Maybe the police just stop people randomly and search them, and there can be a 
question, the State's attorney responded, effectively, that such information is irrelevant to the Fourth Amendment question presented in the case. ${ }^{174}$ These very good questions were not the only indications of the Court's sensitivity to the relevance of social science to the task of constitutional interpretation in Wardlow.

Justice Souter, however, posed what we think to be the most central question in this case when he asked, " $[\mathrm{H}]$ ow many innocents are going to be stopped in relation to the whole? That seems to me the tough question." ${ }^{175}$ In posing the question in this way, Justice Souter laid bare the intertwined nature of the Fourth Amendment's balancing test and empirical evidence. However, in response to this question the State's Attorney again referred to ancient legal scholars rather than empirical evidence about the impact of the police practice in question. ${ }^{176}$ In our view, Wardlow and cases like it cannot be adequately decided without attention to this question and the previous questions posed by other justices of the Court.

The paucity of social science research presented to the Court provided the majority with a rationale for not adopting

racial element involved, a white policeman in a black neighborhood. Say, that in that neighborhood, people are frightened of the police and they run away. They just don't want to get involved...

\footnotetext{
${ }^{174}$ See id. at *14*15 (Mr. Devine speaking):
}

My response is that-that since Terry, when the Court discussed that issue, this Court has said that under the Fourth Amendment we apply a colorblind test. We look at the balancing outside of those issues, and if those issues are there, application of sanctions under the Fourth Amendment isn't going to resolve them. They should be handled, as this Court has said, as recently as Wren, either by equal protection claims or section 1983 claims or administrative charges within the particular police department.

I would submit, Your Honor, that if we start to classify when we can do a Fourth Amendment stop, based on Teryy, or arrest based on probable cause, considering what the race of the police officer is, the race of the individual that is involved, the Fourth Amendment will be unworkable and will prevent the police officers from doing the job that we want them to do. That's why we believe a bright line rule is appropriate here.

${ }^{175} I d$.

176 "Well, Your Honor, I would again note that flight, going back to the time of the Framers has been considered suspicious behavior. . . ." Illinois v. Wardlow, No. 981036, 1999 WL 1034479 at *9 (U.S. Nov. 2, 1999) (oral argument). 
either of the bright line rules urged by the parties-both of whom, understandably, sought to gain greater clarity regarding the contours of the Fourth Amendment protections. Lower courts had addressed the relationship between flight from a police officer and reasonable suspicion, as well as flight from a police officer in a high crime area, both in favor of reasonable suspicion findings and against them. ${ }^{177}$ But because neither side presented empirical research studies dealing with the relationship between flight and guilt, the Court claimed that it had to rely on "commonsense judgements and inferences about human behavior." 178 After making that elliptical statement, the majority concluded that the police officer who stopped Wardlow had indeed acted in a manner that comported with the Constitution.

In a world in which there really is no research available to inform the Court's commonsense judgments about human behavior, perhaps this conclusion would not be troubling. If relevant research is indeed lacking, then personal experience (to which much reference was made in oral arguments), and citations to Proverbs ${ }^{179}$ may be better than guessing. At least we could be confident that the Court was doing the best it could to make a difficult decision without social authority to help guide it. But what if there is social science research available to inform the Court's commonsense judgments? Does it still make sense to be confident about the Court's ability to make difficult decisions concerning the requisite balance between liberty and order without consulting it? Do we really believe that the unadorned commonsense judgments of the justices of the Supreme Court are adequate to determine the scope of individual rights?

Justice Stevens' dissent provides a welcome break from the opaque reasoning behind the majority's common sense judgments in Wardlow. To call into question Illinois' assumption that

177 See David Harris, Particularized Suspicion, Categorical Judgments: Supreme Court Rhetoric Versus Lower Court Reality Under Terry v. Ohio, 72 ST. JoHN's L. REv. 975, 990996 (1998) (collecting cases).

${ }^{178}$ Wardlow, 120 S Ct. at 676, citing U.S. v. Cortez, 449 U.S. 411, 418 (1981).

179 "The wicked flee when no man pursueth, but the righteous are bold as a lion." Proverbs 28:1 (King James). 
flight from a police officer is always aberrant or abnormal, Justice Stevens cited social authority indicating that $43 \%$ of African-Americans consulted in one poll consider "police brutality and harassment a serious problem in their own community;" that minorities experience street stops at numbers disproportionate to their representation in the population of many cities; ${ }^{181}$ that African-Americans are more than twice as likely to be dissatisfied with police practices than white residents in twelve cities surveyed; ${ }^{182}$ and that police departments in some major urban areas recognize that racial bias on the part of the officers employed hampers the effectiveness of the force. ${ }^{183}$ By pointing to this research, Justice Stevens sought to demonstrate that flight from a police officer-especially by a member of a minority group-is not necessarily the product of guilt, but may be triggered by fear or dislike of police officers by an innocent person.

The five Justices in the majority apparently agreed with the four dissenters on this particular point, as the Court unanimously rejected the Petitioner's call for a bright-line rule regarding flight. While the majority did not cite the authority proffered by the dissenters, the majority did reference the arguments of Respondent and amici-arguments relying on this authority and incorporated in the dissent-and did suggest that flight is not necessarily indicative of ongoing criminal activity. But that point, said the majority, "does not establish a violation of the Fourth Amendment."

Justice Stevens' evidence, however, did not really address the most central legal and empirical question in Wardlow: namely, whether the risk that an innocent person may be stopped when police officers rely on flight in an area known for

${ }^{180}$ Wardlow, 120 S. Ct. at 673 n. 7 (citing Johnson, American's views on Crime and Law Enforcement: Survey Findings, National Institute of Justice Journal 13 (Sept. 1997)).

${ }^{181}$ See id. (citing Brief for NAACP Legal Defense \& Education Fund as Amicus Curiae at 17-19).

${ }^{182}$ See id. (citing U.S. Dept. of Justice, Bureau of Justice Statistics, S. Smith, Criminal Victimization and Perceptions of Community Safety in 12 Cities, 25 (June 1998)).

${ }^{183}$ See id. at 673 n. 9 (citing Report of the Independent Commission on the Los Angeles Police Department 69 (1991)).

${ }^{184}$ Id. at 677. 
narcotics trafficking is too high to be constitutionally acceptable. Neither the majority nor the dissent looked to empirical evidence on this central question in Wardlow. Instead, as noted, the majority chose to answer the question with reference to commonsense judgments. This is precisely the kind of reasoning that critics of balancing abhor; however, this kind of decision-making is not inevitable. It can be improved with greater reliance on social authority.

A pathbreaking study of street stops in New York City released on December 1, 1999, about six weeks before Wardlow was published, provides critical insight to the central question in Wardlow. ${ }^{185}$ While a study of Chicago street stops would have been more apt, this study of police activity in a major urban area contains information directly pertinent to the central legal and empirical question in Wardlow and surely constitutes social authority for the case.

The New York OAG study was completed in order to "move the issue of police-community relations to a place where reality drives perceptions rather than the reverse." ${ }^{186}$ The study is an analysis of 175,000 forms collected over one year that is compared with census data, crime statistics and demographic information to yield a statistically valid, quantitative view of the practice of "stop and frisk." While the executive summary of the study indicates that perceptions of racial injustice in polic-

${ }^{185}$ Although the report was not issued early enough for it to be included in the briefs in the case, it was available to the Justices when they wrote the opinion. We explore the report here as an example of evidence that could be used in making a reasonableness determination rather than condemning the court for overlooking the report.

${ }^{186}$ Civil Rights Bureau, Off. of the Att'y Gen., The New York City Police Department's "Stop E' Frisk" Practice: A Report from the Office of the Attorney General, iv (December 1, 1999) (hereinafter "OAG Report").

${ }^{187}$ The forms that provide the fodder for this analysis are known as "UF-250s." According to the NYPD's Patrol Guide, a police officer who stops and frisks an individual must complete a UF-250 if a person is (1) stopped by force; (2) stopped and frisked; (3) arrested; (4) stopped and refuses to identify oneself. Id. at 89 . In policesuspect encounters that fall outside these four contexts, a police officer may fill out a form if he or she desires to do so, but does not necessarily have to do so. The pool of forms analyzed in the study contained about three quarters mandated reports and the rest voluntary. Id. at 91 . The forms covered stops that occurred in 1998 and the first three months in 1999. Id at v. 
ing spurred the initiation of the research, ${ }^{188}$ the study also provides a wealth of information beyond the racial impact of stops in New York. Particularly notable for our purposes is data collected in the study connecting the rate of stops made by police and subsequent arrests.

The relationship between stops and arrests is a potential method of determining how good an indicator a particular factor for police action must be. The relevance of this relationship was noted by Justice Stevens in dissent. Justice Stevens pointed in passing to a newspaper article reporting that in 1997, New York City's Street Crimes Unit made 45,000 stops, only $20 \%$ of which resulted in arrests. ${ }^{189}$ Justice Stevens then wrote, "even if these data were race neutral they would still indicate that society as whole is paying a significant cost in infringement in liberty by these virtually random stops." ${ }^{\text {190 }}$ This issue-namely, how significant is the cost that society must pay to achieve a certain level of safety-we submit, is precisely the question that must be answered in Wardlow and in every case in which the Fourth Amendment is in question. Justice Stevens' reference to empirical evidence provides an excellent opportunity to have this discussion-and to have this discussion in a much more transparent fashion.

The New York OAG Report collects, in addition to racial breakdowns on stops and frisks, a measure of how "good" those stops are: how many of the stops lead to an arrest. Citywide, that ratio was 9:1. ${ }^{191}$ That is, nine stops were made by the NYPD for every eventual arrest. ${ }^{192}$ Here, then, is empirical confirmation of the jurisprudential gap between the reasonable suspicion and probable cause standards. Of course, this particular gap may not be constitutionally justified, and we believe, as Justice Steven's assertion implies, that this kind of empirical information should be reviewed by the Court to determine just how close or wide this gap should be. What is clear is that a lower

\footnotetext{
${ }^{188}$ See id at iv.

${ }^{189}$ See Wardlow, 120 S.Ct. at 681 (Stevens, J., dissenting).

${ }^{190} I d$. at 680 n.8.

${ }^{191}$ See OAG Report, supra note 186.

${ }^{192}$ See id. at 111.
} 
justificatory standard for police action should be expected to, and does in fact result, in more police encounters with more suspects-as the notion of proportionality that we discussed earlier implies.

The citywide ratio masks a great deal. It masks variation in ratios from as low as 6.3:1 for highway and traffic to 26.7:1 for the narcotics task force. ${ }^{193}$ It also masks racial differences in stop-to-arrest ratios. After controlling for crime rates-measured in this study by arrest rates for various offenses-and precinct composition, researchers found that, whether the relevant precinct was majority or minority Black, the comparison between the stop-to-arrest rates for Blacks and the same rates for whites was almost always 2:1. ${ }^{194}$

This analysis provides an even stronger case for the claim made by the Wardlow amici that minority individuals have more encounters with police that do not always trigger an initiation of the criminal justice process than do whites. This information, together with that cited by the dissenters, suggests that minority individuals have a relationship with the police that makes interpretation of flight extremely difficult.

These data are somewhat better at answering the central question in Wardlow than the data cited by the dissent. Whereas the latter simply amplified the noisy connection-at least for certain minority groups-between flight from a police officer and guilt, these data show very concretely that minority groups-in the New York metropolitan area, at least-are subjected to a greater amount of official intrusion than are those from other groups, holding constant crime rates and racial composition of the places in which the stops occur. Still, these data do not say very much about the relevance of flight to reasonable suspicion.

${ }^{193}$ See id. at 112, tbl.1.B.1.

${ }^{194}$ See id. tbl. 1C.1. So for example, the stop rate of Blacks in precincts that were less than $10 \%$ Black was 52 stops of Blacks for every 100 Blacks arrested for violent crime. That same rate for whites in the area was 24 , yielding a ratio of 2.17 to 1 . In the more racially varied precincts that ratio was 2.14 to 1 . And in the precincts with the highest proportion of Black residents, the ratio was 2.11 to 1 . There were similarly disparate ratios for Hispanics to whites, but not so extreme as the ratios of Blacks to whites. 
Fortunately, the OAG Report contains still more information. The report collects information on a sample of stops ${ }^{195}$ based on facts that, as reported by the police, clearly meet the constitutional standard of reasonable suspicion according to Terry and its progeny. ${ }^{196}$ Additionally, the report collects information on stops based on facts that courts have decided clearly do not constitute reasonable suspicion. ${ }^{197}$ Moreover, the report collects information pertinent to the most important facts present in Wardlow-suspects who flee from the police in high crime areas. The table on the following page summarizes the OAG Report.

Recall Justice Stevens' assertion that a ratio of five stops for every one arrest is a "significant cost in infringement in liberty." The data presented in this chart reveals that, in New York City, at least, the criteria that the courts have traditionally relied upon to support a finding of reasonable suspicion are very close. They produce a ratio of 7.3 stops for every one arrest. Here, then, is data that could help the Court to think very seriously about whether the price citizens pay for a particular level of safety is too high.

The chart also demonstrates quite clearly that whatever one thinks about the price on liberty of stops generally determined by courts to be constitutionally justified, the stops backed up by reasons typically looked on with disfavor by the courts yield a much higher stop-to-arrest ratio than the constitutionallyjustified stops-in fact, a ratio of 29.3:1.

Here, then, is evidence that allows for comparison of categories of evidence typically considered to meet (and not to meet) constitutional standards. When cross-classified by race, wrongful stops-those that did not articulate reasonable suspicion-occurred at roughly the same rates for Blacks, Latinos, and whites: $15.7 \%, 14.3 \%$ and $16.6 \%$ respectively. These are not statistically significant differences. Interestingly, while it is clear

${ }^{195}$ For this portion of the analysis, a sample of 15,000 out of the database of 175,000 stops were used. See OAG Report, supra note 186, at 135 .

${ }^{196}$ Categories of stop rationales were developed, and then the UF-250 forms were coded in accordance with these categories. See OAG Report, supra note 186, at 135136. The researchers discussed with lawyers for the OAG the constitutional standard to code, and a great deal data was excluded as providing insufficient data, as the summary table below indicates.

${ }^{197}$ See id. at 135. 
that Blacks and Hispanics in New York are subject to greater levels of intrusion, the data appear to say only that clearly wrongful stops occur as often for whites as for people of color.

With respect to the particular issue presented in Wardlow, the chart provides a fascinating picture of police work. Stops reported as undertaken because the suspect fled the scene result in a very high stop-to-arrest ratio-a ratio of $26: 1$. This ratio is quite close to that of stops based on factors generally understood to fail to satisfy the reasonable suspicion test. Note that even when flight in a high crime area is considered, the ratio between stops and arrests lowers, but it does not lower by much. It stands at 20.3:1. These data support the Wardlow dissenters' argument that flight may be caused by a whole host of reasons that are not indicative of criminal activity.

Importantly, however, the Wardlow Court did not discuss merely the suspicious nature of flight generally; rather, the Court assessed whether flight "upon noticing the police" "flight [that] was motivated by the presence of a police officer" ${ }^{\prime 199}$ was suspicious enough to justify a police stop. The researchers who analyzed the data in the New York OAG Report categorized this more specialized type of flight in a category separate from the general flight category. The ratio between stops and arrests with respect to flight to elude the police suggest a tighter relationship than the general flight code. Indeed the 15.8:1 ratio of stops to arrests for this category is quite close to the ratio of the other categories of information for stops deemed insufficient to determine constitutionality with confidence-an indication that Wardlow is indeed the close case that it appears on first impression to be. When the data on flight to elude police are confined to high crime areas - the very context presented by the facts in Wardlow - a different relationship between stops and arrests emerges. These data reveal a stop-toarrest ratio of $45: 1 .^{200}$

\footnotetext{
${ }^{198}$ Wardlow, 120 S.Ct. at 676.

${ }^{199} I d$. at 679 (Stevens, J., dissenting).

${ }^{200}$ Explanatory notes for categories used in analyzing the OAG report and in Table 2 below:

"The researchers considered these categories of information reported by an officer as evidence meeting the reasonable suspicion justificatory standard: crime observed (observed drug sale, jumping turnstile/metrocard fraud, theft of service, buy \& bust, graffiti); fit description (fit description, identified/information from third party at
} 


\section{TABLE 2: SUMMARY OF THE OAG REPORT}

\begin{tabular}{|l|l|c|c|}
\hline & \multicolumn{1}{|c|}{$\begin{array}{c}\text { TOTAL } \\
\text { STOPS }\end{array}$} & $\begin{array}{c}\text { STOPS RESULTING IN } \\
\text { ARREST }\end{array}$ & $\begin{array}{c}\text { RATIO OF STOPS } \\
\text { TO ARREST }\end{array}$ \\
\hline $\begin{array}{l}\text { Facts articulate rea- } \\
\text { sonable suspicion }\end{array}$ & 2,678 & 368 & 7.3 \\
\hline $\begin{array}{l}\text { Facts do not articu- } \\
\text { late reasonable suspi- } \\
\text { cion }^{b}\end{array}$ & 673 & 23 & 29.3 \\
\hline $\begin{array}{l}\text { Insufficient informa- } \\
\text { tion }^{c}\end{array}$ & 1,032 & 76 & 13.6 \\
\hline $\begin{array}{l}\text { FLIGHT ALONE } \\
\text { Fleeing crime scene }\end{array}$ & 104 & 4 & 26 \\
Attempted flight & 79 & 5 & 15.8
\end{tabular}

scene, bail jumping, known and wanted by police/active warrant); weapon observed (waistband activity, bulge in waistband, observed object that could be (appeared to be) gun weapon, laser light activity/toy guns); suspicious plus (eluding the police plus other factors, location prone to robbery plus suspicious behavior (pacing, talking to known dealers, loitering), carrying theft equipment/other paraphenalia, placing/retrieving object (drugs), location known for drug activity plus "suspicious behavior" (pacing, standing around talking with passersby or known drug dealers), location known for prostitution plus suspicious behavior, suspected break-in/burglary/on fire escape, extended observation of suspicious activity (trying multiple car doors, extended observation activity, walking back and forth on same street, etc.).

'The researchers considered these categories of information reported by an officer as evidence not meeting the reasonable suspicion justificatory standard, rendering the reported stop unconstitutional: Activity deemed suspicious (pocket/clothing activity, bulge in clothing, attempting to elude police, suspicious behavior (nervousness, pacing), suspicious clothing, association with a suspect/person arrested/known dealer, gang affiliation (known member or clothing), loitering, known to police, loitering on subway platform, looking in to parked cars/trying one door, black or silver object/exchange of object; (wrong place), location known for drug activity, location prone to robbery/burglary/grand larceny, location known for prostitution.

'The researchers considered these categories of information reported by an officer as evidence insufficient to determine whether or not the reasonable suspicion standard was met: person in area that crime or suspicious activity was reported, fleeing crime scene, suspected drug sale, observed drug use, suspected alcohol consumption/open bottle, observed alcohol consumption/open bottle, moving furniture/carrying out of place objects (computers), panhandling, insufficient information, knife in pocket, questioned individual in an ongoing investigation.

'The data on flight were categorized in two ways: attempting to elude police, eluding police plus other factors/suspicious activity, and fleeing the crime scene. The researchers considered information relevant to the first category evidence of an unconstitutional stop, and they considered evidence relevant to the second category insufficient to make a determination. We are grateful to Jeffrey Fagan, Center for Violence Research and Prevention, Columbia University for his analysis. 


\begin{tabular}{|l|l|l|l|}
\hline FLIGHT IN HIGH & & & \\
CRIME AREA & & & \\
Fleeing crime scene & 61 & 3 & 20.3 \\
Attempted flight & 45 & 1 & 45 \\
\hline TOTAL & 4,383 & 467 & 9.4 \\
\hline
\end{tabular}

This astoundingly high relationship between stops and arrests is suggestive that in high-crime urban communities where the population is disproportionately minority, flight from an identifiable police officer is a very poor indicator that crime is afoot. The data thus reveal an irony. The Court relied on "commonsense" to come to a conclusion that two indicators of criminality (flight from police and presence in a high crime neighborhood) more reliably justify police action than just one indicator (flight from a police officer generally). This commonsense conclusion may well hold up outside of high crime urban areas. In New York City, however, the data suggest otherwise.

Whatever the ambiguities of the facts presented by this case, the data in the chart above provide a measure of the intrusiveness of police stops. The data demonstrate clearly that New York police (and, therefore, likely urban police generally) engage in many more stops than arrests. The data in the New York OAG Report also indicate that minorities in New York experience a much greater number of stops than do whites in New York City. These same data also suggest that even though minorities experience a higher number of stops, they do not experience a higher number of unconstitutional stops than do whites. Finally, the data in the chart above provide a comparative measure of the intrusiveness of police stops for different categories of reasons.

Of course, none of these data provide a definitive answer to Justice Souter's critically important question. We certainly are not here suggesting that the Court determine that all states ought to measure whether police properly observe the standards set out in Terry by making sure that the stop-to-arrest ratio meets a certain preset number. Clearly, such a rule would be problematically subject to manipulation. We are arguing, however, that these ratios help to make clear the normative decision the Court must make regarding just how much intrusion into 
our lives will be constitutionally justified by law enforcement methods. These data do not provide a definitive answer, but they $d o$ indicate that this intrusion can be measured in some way and they would render more transparent the Court's normative choices and analysis. The data make plain that even indicators traditionally considered to be good indicators of crime may well require society to shoulder a quite high level of intrusion into personal liberties. Perhaps society believes that this level of intrusion is justified. One thing is clear: we could be much more confident of such a conclusion if the Court had a very public and forthright discussion of the requisite probability of certainty required to justify a police stop or an arrest based on empirical data such as those presented here.

\section{CONCLUSION}

In this Foreword, we call for increased attention to social science research in constitutional criminal procedure adjudication. In most criminal procedure cases-and certainly in Dickerson and Wardlow-the Court's decision-making process and opinions would be greatly improved if the justices discussed and referenced the relevant empirical research. By addressing social science data, the Court would articulate more explicitly the values of interest-for example, how effective Miranda warnings are in apprising accused persons of their right to silence, or how reliable fleeing from the police is in predicting criminal behavior. This, in turn, would make more transparent the interpretive choices that underlie the balancing of liberty and order interests.

In writing this Foreword together, we intend to emphasize that the turn to social science does not tilt the playing field in any particular ideological direction. It does not favor either of Herbert Packer's two models of criminal procedure, ${ }^{201}$ nor John Griffith's family model. ${ }^{202}$ Nor is it outcome determinative. It does not answer the question presented, nor does it guarantee a

${ }^{201} \rightarrow$ Herbert L. Packer, Two Models of the Criminal Process, 113 U. PA. L. REv. 1 (1964).

${ }^{202} \rightarrow \circ$ John Griffiths, Ideology in Criminal Procedure or a Third "Model" of the Criminal Process, 79 YALE L. J. 359 (1970). 
right answer. In the first place, social science evidence is often in dispute and calls for interpretive judgment itself. But more importantly, the outcome under a balancing-of-interests approach is determined by a normative assessment of the order/liberty relationship, and not simply by quantifying the values of interest. In this sense, we are not arguing that empirical evidence will resolve constitutional litigation, nor that social science will constrain the Court's decision-making-although, if treated respectfully, it will of course preclude the Court from making decisions based on improper empirical findings. What we are arguing, instead, is that it will improve the quality of the Court's decision-making in constitutional criminal procedure and render more transparent and open to criticism the Court's opinions.

We anticipate at least three major criticisms and will address these in conclusion. The first has to do with institutional competence. Many may respond that courts are simply not capable of dealing with complicated and conflicting social science data. Judges and lawyers, for the most part, are not trained to assess social science evidence and may not have advanced degrees in the social sciences. To make matters worse, a lot of the empirical research that is likely to reach the courts may be funded or conducted by ideologically motivated groups. How are the courts to deal with such studies?

In the article that originated the concept of social authority, John Monahan and Laurens Walker offer a set of guidelines for courts to use to assess social science research. Monahan and Walker point to critical review as a mechanism by which courts could evaluate social science research, ${ }^{203}$ and they discuss methods by which courts could assess the validity and generalizability of social science findings-including the question of research sponsorship. ${ }^{204}$ Monahan and Walker point out, moreover, that courts are unlikely to undertake these evaluations by themselves and on their own initiative. The authors suggest instead that the adversarial process itself will address some concerns about the ability of courts to adequately appraise social science re-

\footnotetext{
${ }^{203}$ See Monahan \& Walker, supra note 60 , at $499-501$.

${ }^{204}$ See id. at 501-507.
} 
search. ${ }^{205}$

Once courts, and the Supreme Court in particular, more forthrightly indicate an interest in social science relevant to criminal procedure questions, litigating parties will be quick to make arguments regarding the strengths and weaknesses of empirical research. ${ }^{206}$ It also follows from our argument here that social scientists and the professional organizations to which they belong should be more involved in amicus brief writing presenting issues within their competence, which would further add to the strength and validity of social science research presented to the Court. ${ }^{207}$

A second likely criticism is that most of the values of interest-especially personal liberty and efficient law enforcementare incommensurable and therefore cannot properly be compared. Some scholars may respond to our proposal that any balancing of liberty and order will inevitably favor the government because one individual's interest in precluding an intrusion on her space and time will always lose out against the enormity of society's collective interest. ${ }^{208}$ Lawrence Tribe, for instance, has argued that "in that kind of calculus, the costs will always seem weightier than the benefits. The benefits will be elusive, intangible, diffuse." ${ }^{209}$ As Dorf suggests, "Liberals distrust law and economics because it undervalues "soft" variables . ...."210 These values, some may argue, are incommensurate among themselves and as against the interests of law enforcement. In a similar vein, Weisselberg argues, in the Miranda context, that

[a] cost/benefit analysis is utterly unsuited to the task, for there is no

${ }^{205}$ See id at 512.

${ }^{206}$ See Dorf, supra note 37, at 56 (claiming that parties and amici will follow the lead of the Court if it begins to rely to a greater extent on policy and empirical arguments).

${ }^{207}$ See James R. Acker, Social Science in Supreme Court Criminal Cases and Briefs: The Actual and Potential Contribution of Social Scientists and Amici Curiae, 12 L. \& HUM. BEH. 25,42 (1990).

${ }^{208}$ See Scott E. Sunby, A Return to Fourth Amendment Basics: Undoing the Mischief of Camara and Terry, 72 MINN. L. REv. 383, 439 (1988).

${ }^{209}$ Tribe, supra note 29 , at 157.

${ }^{210}$ Dorf, supra note 37, at 46. 
single metric that can encompass Miranda's costs and its benefits. . . [O]ne cannot establish empirically the ordering of Fifth Amendment values ... and the needs of law enforcement. These values, interests, and needs are incommensurate; they cannot be measured along the same scale.

With respect to the specific argument that an individual's particular interest is never weighty enough to overcome society's collective interest in safety and order, we need only point out that aggregated societal interests appear on both sides of the balance, not just on the side of safety. As a result, it is not entirely correct that social order will always be weightier than individual liberties. But the concern about the incommensurability of the costs and benefits of different levels of government respect for individual interests in privacy, autonomy and property is more difficult to address. ${ }^{212}$

One answer is that acknowledging this kind of incommensurability does not necessarily preclude the comparability of society's interests in both liberty and order. ${ }^{213}$ Those who criticize the use of empirical evidence to inform the Court's balancing analysis are not primarily concerned with this more pragmatic approach. After all, this very approach produced the Miranda opinion in the first place. Recall that Miranda's chief supporters characterize the opinion in this way. Rather, critics are concerned that the particular values they most cherish will be muted if decision makers use empirical evidence to create a cardinal scale against which law enforcement needs and various constitutional values can be arrayed-a scale that critics do not believe exists.

We believe this concern about empirical evidence is somewhat misplaced. These values, we contend, inevitably are and must be compared in complex criminal procedure cases. Without some evidence, the Court's pronouncements about the impact of its decisions amount to little more than bald assertions of "common sense" or "intuition." Rather than fearing the utili-

\footnotetext{
${ }^{211}$ Weisselberg, supra note 35 , at 170-71.

${ }^{212}$ Indeed, it is a very controversial and hot topic in law today. See generally, Symposium: Law and Incommensurability, 147 U. PA. L. REV. 1169 (1998).

${ }^{213}$ See Ruth Chang, Comparison and the Justification of Choice, 147 U. PENN. L. REV. 1569 (1998).
} 
zation of empirical and social science evidence in balancing order and liberty interests, the Court and the advocates appearing before it should strive to measure these values to the very best of their ability.

Finally, a third criticism is that our approach makes it too easy for judges to insert their own ideological predispositions into the resolution of the empirical questions. Some may argue that the real decision-making process will actually be hidden in technical and purportedly "neutral" discussions of the social science data. Worse yet, it will have the aura of "science" and "objectivity" and will therefore be more insulated from criticism. Rather than being more transparent, some may argue, the reliance on science will mask or minimize the normativity and insulate it from attack. ${ }^{214}$

There is, undoubtedly, such a risk. A court deciding the Dickerson case could, of course, fudge or nudge the science and find that the Miranda regime has had such an exorbitant effect on law enforcement that the warnings have to be abandoned. But that would not insulate the opinion from criticism. It would in fact expose the decision-making process to further criticism from advocates and the public. In some cases, it is precisely the exposure of the underlying social science that will afford more accountability and transparency, and may allow for more criticism and revision. In some cases, social science may counteract bias, or at least highlight it. The Leon case demonstrates this well, since both the majority and dissent relied on the same empirical evidence.

These are important criticisms that merit more debate and discussion than this Foreword would allow. Our firm conviction is that the inevitable obstacles of institutional competence, incommensurability, and scientific myth do not derail our proposal. To conclude, we suspect, and we hope, that more infusion of social science will likely highlight potential biases, will inspire judges to make more narrow, ${ }^{215}$ limited and provi-

${ }^{214}$ See Richard Lempert, "Between Cup and Lip": Social Science Influences on Law and Policy, 10 L. \& Pol. 167, 188-90 (discussing court use of social science for legitimation and strategic purposes).

${ }^{215} \rightarrow$ Faigman, supra note 38. 
sional decisions, ${ }^{216}$ and, at a minimum, will hold judges more accountable.

${ }^{216}$ Recall that the Court's decision in Leon rested on an empirical determination about the impact of the exclusionary rule on real-life police conduct, and Justice Blackmun noted that "the provisional nature of empiricism invites testing and the prospect of change." See supra notes 66-68 and accompanying text for further discussion. See also Dorf, supra note 37 at 61-69 (discussing the concept and benefits of provisional adjudication). 